\title{
A Comprehensive Review of the Phytochemical, Pharmacological, and Toxicological Properties of Tribulus terrestris L.
}

\author{
Ruxandra Ștefănescu ${ }^{1, *} \mathbb{1}$, Amelia Tero-Vescan ${ }^{2}$, Ancuța Negroiu ${ }^{1}$, Elena Aurică ${ }^{1}$ and \\ Camil-Eugen Vari ${ }^{3}$ (i) \\ 1 Department of Pharmacognosy and Phytotherapy, Faculty of Pharmacy, George Emil Palade University of \\ Medicine, Pharmacy, Science, and Technology of Targu Mures, 540139 Targu Mures, Romania; \\ negroiuanca@yahoo.com (A.N.); ele_aurica@yahoo.com (E.A.) \\ 2 Department of Biochemistry, Faculty of Pharmacy, George Emil Palade University of Medicine, Pharmacy, \\ Science, and Technology of Targu Mures, 540139 Targu Mures, Romania; amelia.tero-vescan@umfst.ro \\ 3 Department of Pharmacology and Clinical Pharmacy, George Emil Palade University of Medicine, Pharmacy, \\ Science, and Technology of Targu Mures, 540139 Targu Mures, Romania; camil.vari@umfst.ro \\ * Correspondence: ruxandra.stefanescu@umfst.ro or ruxandra.braic@yahoo.com; Tel.: +40744397981
}

Received: 13 March 2020; Accepted: 5 May 2020; Published: 12 May 2020

\begin{abstract}
The general spread of Tribulus terrestris L. (South Africa, Australia, Europe, and India), the high content of active ingredients (in particular sterol saponins, as well as flavonoids, tannins, terpenoids, phenol carboxylic acids, and alkaloids), and its frequent uses in folk medicine, and as food supplements highlight the importance of evaluating its phytopharmacological properties. There are miscellaneous hypotheses that the species could have a high potential for the prevention and improvement of various human conditions such as infertility, low sexual desire, diabetes, and inflammatory diseases. Worldwide, numerous herbal supplements are commercialized with indications mostly to improve libido, sexual performance in both sexes, and athletic performance. Phytochemical studies have shown great disparities in the content of active substances (in particular the concentration of furostanol and spirostanol saponoside, considered to be the predominant active ingredients related to the therapeutic action). Thus, studies of experimental pharmacology (in vitro studies and animal models in vivo) and clinical pharmacology (efficacy and safety clinical trials) have sometimes led to divergent results; moreover, the presumed pharmacodynamic mechanisms have yet to be confirmed by molecular biology studies. Given the differences observed in the composition, the plant organ used to obtain the extract, the need for selective extraction methods which are targeted at the class of phytocompounds, and the standardization of T. terrestris extracts is an absolute necessity. This review aims to highlight the phytochemical, pharmacological, and toxicological properties of $T$. terrestris, with a focus on the contradictory results obtained by the studies conducted worldwide.
\end{abstract}

Keywords: Tribulus terrestris; phytopharmacology; saponosides

\section{Introduction}

Tribulus terrestris (TT) is a plant that grows especially in South Africa, Australia, India, and Europe. It is part of the Zygophyllaceae family, a widespread family with 25 genera and about 250 species. TT is a crawling herbal plant that generally grows in arid climates and sandy soils and grows up to one meter high. The name Tribulus comes from the Greek name "tribolos" which means spike fruit. The fruits are used in traditional Chinese medicine (TCM), in Ayurvedic medicine in India, and traditional medicine in Bulgaria for the treatment of different conditions [1]. In addition, the fruits have monographs in the Japanese Pharmacopoeia, 16th Ed. (2012), Korean Pharmacopoeia, 
9th Ed. (2007), Pharmacopoeia of China (2005), and Siddha Pharmacopoeia India, Vol. 1 (2008) (taxonomy validated in http://mpns.kew.org/mpns-portal/). Many compounds with a variety of biological properties and chemical structures have been identified in TT extract, especially steroidal saponins, flavonoids, tannins, terpenoids, polyphenol carboxylic acids, and alkaloids. The composition of TT extract depends on various factors such as the extraction method and whether roots, leaves, or fruits have been used.

Furthermore, the composition and biological activity of TT depends on growth conditions, including soil quality, but also the harvesting period [2]. As shown by Dinchev et al. [3], the highest content of saponins in the aerial parts was met during the preflowering and flowering periods. However, a correlation could not be found between the geographical and ecological conditions and the chemical composition. Nevertheless, remarkable variations (different concentrations in compounds as well as the absence of some compounds) were noticed between samples collected from the same country [4]. Worldwide, there are many pharmaceutical preparations and herbal supplements that contain extracts standardized in steroidal saponins. These are mainly indicated in libido disorders for both males and females, erectile dysfunction, and abnormal sperm motility, but data from the literature are somewhat controversial regarding the efficacy of TT extracts in such disorders [5]. Increased consumption of TT supplements has also been observed in athletes as they continually seek natural sources for boosting their performance.

Several reviews have been published in recent years. Table 1 comprises all the reviews related to TT found in the scientific literature.

Table 1. Previous reviews.

\begin{tabular}{|c|c|c|c|c|}
\hline $\begin{array}{l}\text { Year of the } \\
\text { Review }\end{array}$ & Main Topic & Years Surveyed & Limitations & Reference \\
\hline 2005 & $\begin{array}{l}\text { Phytochemistry and } \\
\text { pharmacology }\end{array}$ & $<2004$ & & [6] \\
\hline 2014 & TT supplements & NS & & [1] \\
\hline 2014 & $\begin{array}{l}\text { Phytochemistry and } \\
\text { pharmacology }\end{array}$ & & short review & [7] \\
\hline 2014 & $\begin{array}{l}\text { Phytochemistry and } \\
\text { pharmacology }\end{array}$ & NS & short review & [8] \\
\hline 2016 & $\begin{array}{l}\text { Analysis of human and } \\
\text { animal evidence }\end{array}$ & 1968-2015 & & [2] \\
\hline 2016 & Phytochemistry & NS & $\begin{array}{c}\text { Only the composition of fruits was } \\
\text { discussed }\end{array}$ & [9] \\
\hline 2016 & $\begin{array}{l}\text { Phytochemistry and } \\
\text { pharmacology }\end{array}$ & NS & & [10] \\
\hline 2017 & $\begin{array}{l}\text { Phytochemistry and } \\
\text { pharmacology }\end{array}$ & NS & & [11] \\
\hline 2018 & Male infertility & & short review & [5] \\
\hline 2019 & $\begin{array}{l}\text { Phytochemistry and } \\
\text { ethnomedicine }\end{array}$ & NS & brief presentation of constituents & [12] \\
\hline 2019 & Male infertility & NS & & [13] \\
\hline 2019 & $\begin{array}{l}\text { Phytochemistry and } \\
\text { pharmacology }\end{array}$ & 1965-2017 & & [14] \\
\hline 2020 & $\begin{array}{l}\text { Phytochemistry and } \\
\text { pharmacology }\end{array}$ & NS & $\begin{array}{l}\text { the review is based mostly on } \\
\text { Ayurvedic preparation } \\
\text { The pharmacological effects are } \\
\text { briefly presented }\end{array}$ & [15] \\
\hline
\end{tabular}

This review presents the most important phytochemical and pharmacological data with an emphasis on the prominent information related to the chemical composition, pharmacological studies, mechanisms of action, and toxicological data.

The information on TT was compiled via an electronic search of the following major scientific databases: Science Direct, PubMed, Web of Science, and Scopus, from 2000 to 2020. Whenever the published data were relevant for the present review, the search was extended to 1982 (identification of compounds in different organs and toxicological reports). The query was supplemented by searching the reference lists of papers included in the first selection. The search terms were as follows: "Tribulus 
terrestris" alone or in combination with "chemistry", "pharmacology", "effects", and "toxicity". For this review, only full-text articles written in the English language were taken into consideration. Unpublished results or grey literature were not included and only pharmacological actions that demonstrated effects both in vitro and in vivo were discussed in the present review.

\section{Chemical Composition}

TT fruits contain important secondary metabolites such as saponins, polyphenolic compounds, and alkaloids. The steroidal saponins are mainly furostanol and spirostanol type (Figure 1). The furostanol saponins are believed to be biogenetic precursors of the spiro analogs. To date, over 70 different compounds have been identified in TT (Table 2).
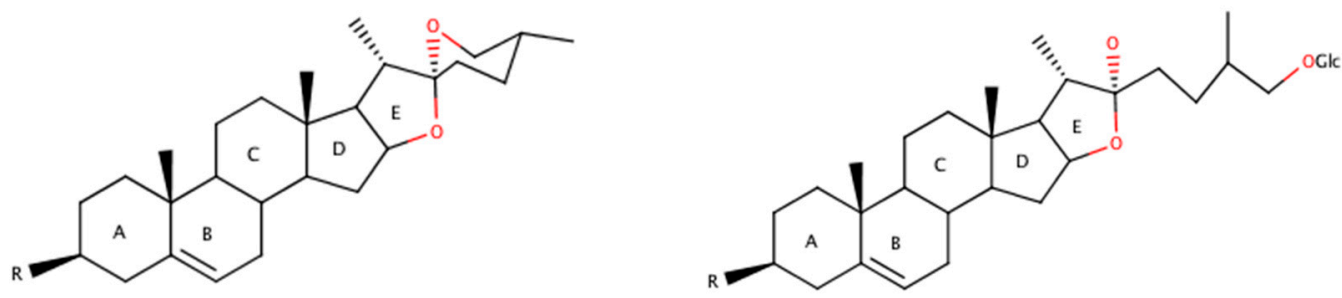

Figure 1. Spirostanol (left) and furostanol (right) saponins.

Table 2. Chemical compounds identified in Tribulus terrestris (TT).

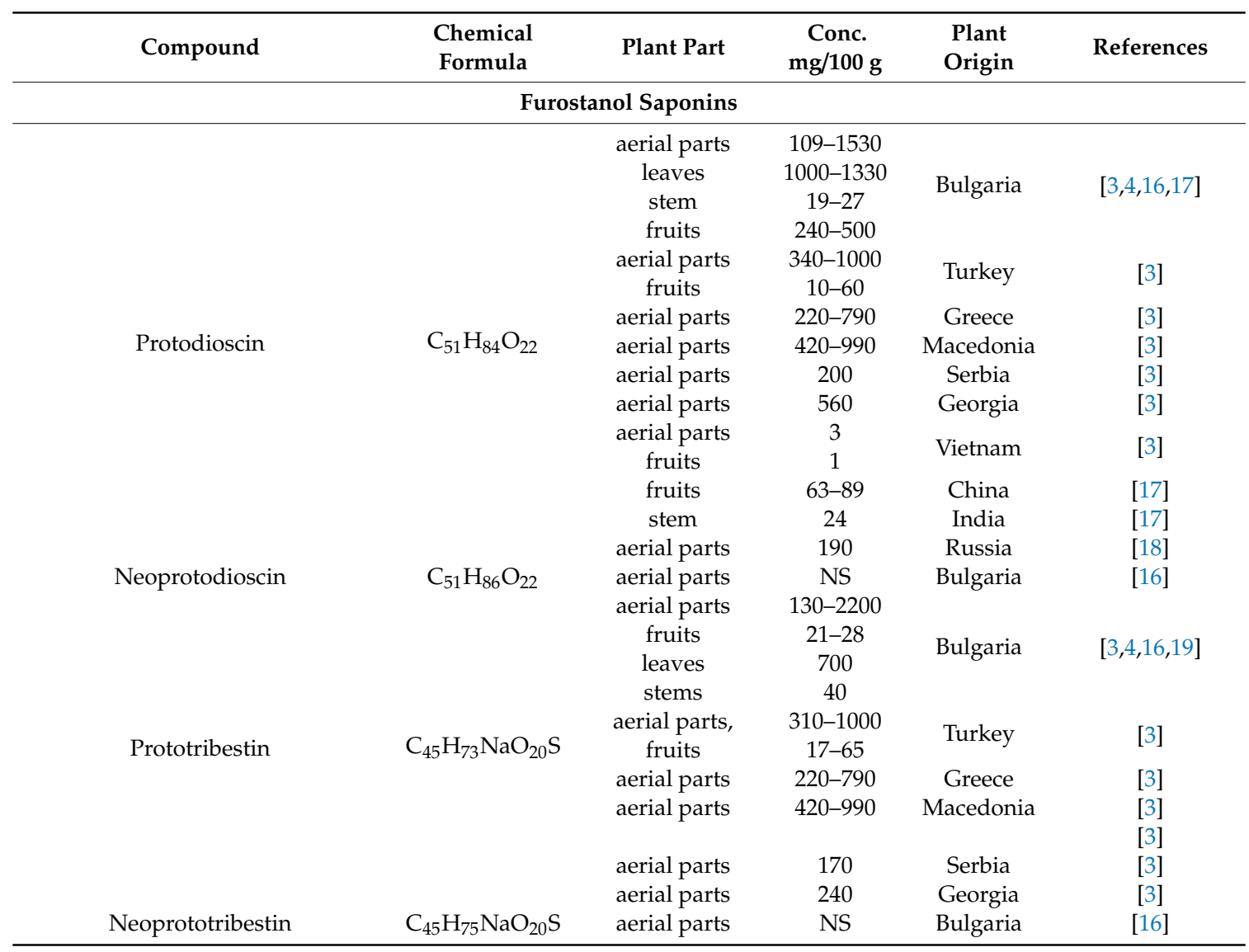


Table 2. Cont.

\begin{tabular}{|c|c|c|c|c|c|}
\hline Compound & $\begin{array}{l}\text { Chemical } \\
\text { Formula }\end{array}$ & Plant Part & $\begin{array}{c}\text { Conc. } \\
\mathrm{mg} / 100 \mathrm{~g}\end{array}$ & $\begin{array}{l}\text { Plant } \\
\text { Origin }\end{array}$ & References \\
\hline Terestrinin A & $\mathrm{C}_{33} \mathrm{H}_{48} \mathrm{O}_{9}$ & fruits & NS & China & [20] \\
\hline \multirow{2}{*}{ Terestrinin B } & \multirow{2}{*}{$\mathrm{C}_{60} \mathrm{H}_{95} \mathrm{O}_{30}$} & root & NS & Georgia & [21] \\
\hline & & fruits & NS & China & [20] \\
\hline Terrestrinin D & \multirow[t]{3}{*}{$\mathrm{C}_{33} \mathrm{H}_{50} \mathrm{O}_{10}$} & fruits & 5.6 & China & {$[22,23]$} \\
\hline Terestrinin J-T & & whole plant & NS & China & [24] \\
\hline Terestroside A & & root & NS & Georgia & [21] \\
\hline Terrestrosin $\mathrm{K}$ & $\mathrm{C}_{51} \mathrm{H}_{82} \mathrm{O}_{24}$ & fruits & 1.27 & China & [22] \\
\hline Terrestrosin I & $\mathrm{C}_{51} \mathrm{H}_{84} \mathrm{O}_{25}$ & $\begin{array}{l}\text { whole plant } \\
\text { fruits }\end{array}$ & NS & China & {$[23,24]$} \\
\hline Tribufuroside D & $\mathrm{C}_{45} \mathrm{H}_{74} \mathrm{O}_{21}$ & fruits & NS & China & {$[23,25]$} \\
\hline Tribufuroside E & $\mathrm{C}_{45} \mathrm{H}_{74} \mathrm{O}_{21}$ & fruits & NS & China & {$[23,25]$} \\
\hline Tribulosaponin A & $\mathrm{C}_{51} \mathrm{H}_{84} \mathrm{O}_{21}$ & fruits & NS & China & [26] \\
\hline \multirow{2}{*}{ Polianthoside D } & \multirow{2}{*}{$\mathrm{C}_{56} \mathrm{H}_{92} \mathrm{O}_{29}$} & root & NS & Georgia & [21] \\
\hline & & fruits & 59.6 & China & {$[22]$} \\
\hline \multicolumn{6}{|c|}{ Spirostanol Saponins } \\
\hline \multirow{11}{*}{ Dioscin } & \multirow{11}{*}{$\mathrm{C}_{45} \mathrm{H}_{72} \mathrm{O}_{16}$} & aerial parts & NS & Egypt & [27] \\
\hline & & aerial parts & 60 & Russia & [18] \\
\hline & & $\begin{array}{c}\text { fruits, leaves, } \\
\text { stem }\end{array}$ & $10-43$ & Bulgaria & {$[3,4,28]$} \\
\hline & & $\begin{array}{l}\text { aerial parts } \\
\text { fruits }\end{array}$ & $\begin{array}{c}6-13 \\
1-2\end{array}$ & Turkey & [3] \\
\hline & & aerial parts & $26-31$ & Greece & [3] \\
\hline & & aerial parts & $13-15$ & Macedonia & [3] \\
\hline & & aerial parts & 87 & Serbia & [3] \\
\hline & & aerial parts & 8 & Georgia & [3] \\
\hline & & aerial parts & $2-220$ & & \\
\hline & & fruits & $0.9-3.4$ & Bulgaria & {$[3,28]$} \\
\hline & & leaves & 62 & & \\
\hline \multirow{6}{*}{ Tribestin } & \multirow{5}{*}{$\mathrm{C}_{39} \mathrm{H}_{61} \mathrm{NaO}_{14} \mathrm{~S}$} & aerial parts & $6.8-28$ & Turkey & [3] \\
\hline & & $\begin{array}{l}\text { fruits } \\
\text { aerial parts }\end{array}$ & $\begin{array}{c}0.5-1 \\
24\end{array}$ & & \\
\hline & & $\begin{array}{l}\text { aerial parts } \\
\text { aerial parts }\end{array}$ & $\begin{array}{c}24 \\
7.3-10\end{array}$ & $\begin{array}{c}\text { Greece } \\
\text { Macedonia }\end{array}$ & {$[3]$} \\
\hline & & aerial parts & 210 & Serbia & {$[3]$} \\
\hline & & aerial parts & 6 & Georgia & [3] \\
\hline & \multirow{4}{*}{$\mathrm{C}_{27} \mathrm{H}_{42} \mathrm{O}_{3}$} & NS & NS & China & [29] \\
\hline \multirow[t]{8}{*}{ Diosgenin } & & NS & NS & Ukraine & [30] \\
\hline & & fruits & 86 & India & [31] \\
\hline & & aerial parts & $0.1-7.7$ & & \\
\hline & \multirow{13}{*}{$\mathrm{C}_{55} \mathrm{H}_{90} \mathrm{O}_{25}$} & fruits & 2.6 & \multirow{3}{*}{ Bulgaria } & \multirow{3}{*}[3]{} \\
\hline & & leaves & 0.8 & & \\
\hline & & stem & 1.7 & & \\
\hline & & $\begin{array}{l}\text { aerial parts } \\
\text { fruits }\end{array}$ & $\begin{array}{c}0.03-1.7 \\
0.14\end{array}$ & Turkey & {$[3]$} \\
\hline & & aerial parts & $1.3-2.4$ & Greece & [3] \\
\hline \multirow{9}{*}{ Tribulosin } & & aerial parts & 0.68 & Macedonia & [3] \\
\hline & & aerial parts & 2.24 & Serbia & [3] \\
\hline & & aerial parts & 0.56 & Georgia & [3] \\
\hline & & aerial parts & 22 & Vietnam & [3] \\
\hline & & fruits & 420 & vietnam & \\
\hline & & fruits & 1 & & \\
\hline & & leaves & 644 & India & [3] \\
\hline & & stem & 185 & & \\
\hline & & whole plant & NS & India & [32] \\
\hline Tigogenin & $\mathrm{C}_{27} \mathrm{H}_{44} \mathrm{O}_{3}$ & fruits & 0.05 & China & {$[22,29,33]$} \\
\hline Terestrinin U & & whole plant & NS & China & [24] \\
\hline Gitogenin & $\mathrm{C}_{27} \mathrm{H}_{44} \mathrm{O}_{4}$ & NS & NS & China & [33] \\
\hline \multirow{2}{*}{ Hecogenin } & $\mathrm{C}_{27} \mathrm{H}_{42} \mathrm{O}_{4}$ & fruits & NS & Taiwan & [34] \\
\hline & $\mathrm{C}_{27} \mathrm{H}_{42} \mathrm{O}_{4}$ & fruits & 0.4 & China & [22] \\
\hline Agovoside A & & fruits & NS & China & [20] \\
\hline Prosapogenin B & & aerial parts & NS & Egypt & [27] \\
\hline 25R-5a-Spirost-3,6,12-trione & $\mathrm{C}_{27} \mathrm{H}_{39} \mathrm{O}_{5}$ & NS & NS & China & [33] \\
\hline 25R-Spirost-4-ene-3,12-dione & $\mathrm{C}_{27} \mathrm{H}_{40} \mathrm{O}_{4}$ & NS & NS & China & {$[33,35]$} \\
\hline 25R-Spirost-4-ene-3,6,12-trione & $\mathrm{C}_{27} \mathrm{H}_{38} \mathrm{O}_{6}$ & NS & NS & China & {$[33,35]$} \\
\hline
\end{tabular}


Table 2. Cont.

\begin{tabular}{|c|c|c|c|c|c|}
\hline Compound & $\begin{array}{l}\text { Chemical } \\
\text { Formula }\end{array}$ & Plant Part & $\begin{array}{c}\text { Conc. } \\
\mathrm{mg} / 100 \mathrm{~g}\end{array}$ & $\begin{array}{l}\text { Plant } \\
\text { Origin }\end{array}$ & References \\
\hline \multicolumn{6}{|c|}{ Cinnamic Acid Amides } \\
\hline \multirow{2}{*}{ Coumaroyltyramine } & \multirow{2}{*}{$\mathrm{C}_{17} \mathrm{H}_{17} \mathrm{NO}_{3}$} & fruits & NS & Taiwan & \multirow{2}{*}[34,36,37]{} \\
\hline & & fruits & NS & China & \\
\hline Feruloyloctopamine & $\mathrm{C}_{18} \mathrm{H}_{19} \mathrm{NO}_{5}$ & $\begin{array}{l}\text { truits } \\
\text { fruits }\end{array}$ & $\begin{array}{l}\text { NS } \\
\text { NS }\end{array}$ & $\begin{array}{l}\text { Taiwan } \\
\text { China }\end{array}$ & {$[36]$} \\
\hline \multicolumn{6}{|c|}{ Quinic Acid Derivatives } \\
\hline 5-p-cis-coumaroylquinic acid & $\mathrm{C}_{16} \mathrm{H}_{18} \mathrm{O}_{8}$ & aerial parts & NS & Egypt & [27] \\
\hline 5-p-trans-coumaroylquinic acid & & aerial parts & NS & Egypt & [27] \\
\hline $\begin{array}{c}\text { 4,5-Di-p-trans-coumaroylquinic } \\
\text { acid }\end{array}$ & & aerial parts & NS & Egypt & [27] \\
\hline 4,5-Di-p-cis-coumaroylquinic acid & & aerial parts & NS & Egypt & [27] \\
\hline \multicolumn{6}{|c|}{ Flavonoids } \\
\hline Tribuloside & $\mathrm{C}_{30} \mathrm{H}_{26} \mathrm{O}_{13}$ & leaves, fruits & NS & India & {$[38]$} \\
\hline Kaempferol & $\mathrm{C}_{15} \mathrm{H}_{10} \mathrm{O}_{6}$ & leaves, fruits & 18 & India & {$[31,38]$} \\
\hline $\begin{array}{l}\text { Astragalin (kaempferol } \\
\text { 3-glucoside) }\end{array}$ & $\mathrm{C}_{21} \mathrm{H}_{20} \mathrm{O}_{11}$ & leaves, fruits & NS & India & [38] \\
\hline Kaempferol 3-rutinoside & $\mathrm{C}_{27} \mathrm{H}_{30} \mathrm{O}_{15}$ & leaves, fruits & NS & India & {$[38]$} \\
\hline Kaempferol-3- gentiobioside & $\mathrm{C}_{27} \mathrm{H}_{30} \mathrm{O}_{16}$ & fruits leaves & NS & China & {$[39,40]$} \\
\hline & \multirow{5}{*}{$\mathrm{C}_{27} \mathrm{H}_{30} \mathrm{O}_{16}$} & leaves & NS & Mauritania & \multirow{4}{*}[4,41-43]{} \\
\hline \multirow{4}{*}{ Rutin } & & fruits, leaves & NS & India & \\
\hline & & fruits, leaves & $70-250$ & Bulgaria & \\
\hline & & fruits & NS & Korea & \\
\hline & & NS & NS & Ukraine & [30] \\
\hline Quercetin & $\mathrm{C}_{15} \mathrm{H}_{10} \mathrm{O}_{7}$ & fruits, leaves & NS & India & [42] \\
\hline $\begin{array}{l}\text { Quercetin-3-O-arabinosyl } \\
\text { galactoside } \\
\text { Isorhamnetin-3-glucoside }\end{array}$ & $\mathrm{C}_{26} \mathrm{H}_{28} \mathrm{O}_{16}$ & fruits leaves & NS & China & {$[39,40]$} \\
\hline \multicolumn{2}{|c|}{ Quercetin-3-O-sophoroside-7-O-glucoside ${ }_{3} \mathrm{H}_{40} \mathrm{O}_{21}$} & leaves & NS & China & {$[39]$} \\
\hline Quercetin-3- gentiobioside & $\mathrm{C}_{27} \mathrm{H}_{30} \mathrm{O}_{17}$ & fruits, leaves & NS & China & {$[39,40]$} \\
\hline Quercetin 3,7-diglucoside & $\mathrm{C}_{27} \mathrm{H}_{30} \mathrm{O}_{17}$ & fruits, leaves & NS & China & {$[39,40]$} \\
\hline Isoquercitrin & $\mathrm{C}_{21} \mathrm{H}_{20} \mathrm{O}_{12}$ & fruits, leaves & NS & China & {$[39,40]$} \\
\hline Luteolin-7-O- $\beta$-D- glucoside & $\mathrm{C}_{30} \mathrm{H}_{18} \mathrm{O}_{11}$ & leaves & NS & China & [39] \\
\hline Isorhamnetin-3-glucoside & $\mathrm{C}_{22} \mathrm{H}_{22} \mathrm{O}_{12}$ & leaves & NS & China & [39] \\
\hline Apiotribosides A-D & & roots & NS & Georgia & [21] \\
\hline \multicolumn{6}{|c|}{ Alkaloids } \\
\hline \multirow{2}{*}{ Harmine } & \multirow{2}{*}{$\mathrm{C}_{13} \mathrm{H}_{12} \mathrm{~N}_{2} \mathrm{O}$} & fruits & 14 & India & [31] \\
\hline & & $\begin{array}{l}\text { fruits, stem, } \\
\text { leaves, roots }\end{array}$ & NS & Turkey & {$[44]$} \\
\hline \multirow[t]{2}{*}{ Harmane } & \multirow[t]{2}{*}{$\mathrm{C}_{12} \mathrm{H}_{10} \mathrm{~N}_{2}$} & $\begin{array}{l}\text { fruits, stem, } \\
\text { leaves, roots }\end{array}$ & NS & Turkey & [44] \\
\hline & & aerial parts & NS & Australia & [45] \\
\hline Harmalol & $\mathrm{C}_{12} \mathrm{H}_{12} \mathrm{~N}_{2} \mathrm{O}$ & $\begin{array}{l}\text { fruits, stem, } \\
\text { leaves, roots }\end{array}$ & NS & Turkey & [44] \\
\hline Harmaline & $\mathrm{C}_{13} \mathrm{H}_{14} \mathrm{~N}_{2} \mathrm{O}$ & $\begin{array}{l}\text { stem, leaves, } \\
\text { roots }\end{array}$ & NS & Turkey & [44] \\
\hline Norharmane & $\mathrm{C}_{11} \mathrm{H}_{8} \mathrm{~N}_{2}$ & aerial parts & NS & Australia & [45] \\
\hline \multirow{2}{*}{ Tribulusterine } & \multirow{3}{*}{$\mathrm{C}_{16} \mathrm{H}_{12} \mathrm{~N}_{2} \mathrm{O}_{2}$} & fruits & NS & Taiwan & [34] \\
\hline & & not specified & NS & India & [46] \\
\hline n-Caffeoyltyramine & & $\begin{array}{l}\text { fruits } \\
\text { fruits }\end{array}$ & NS & $\begin{array}{l}\text { Korea } \\
\text { China }\end{array}$ & {$[36,47]$} \\
\hline Perlolyrine & $\mathrm{C}_{16} \mathrm{H}_{12} \mathrm{~N}_{2} \mathrm{O}_{2}$ & not specified & NS & India & [46] \\
\hline \multicolumn{6}{|c|}{ Amides and Lignanamides } \\
\hline Terrestribisamide & $\mathrm{C}_{13} \mathrm{H}_{18} \mathrm{NO}_{5}$ & fruits & NS & Taiwan & [34] \\
\hline Tribulusamide A & $\mathrm{C}_{36} \mathrm{H}_{36} \mathrm{~N}_{2} \mathrm{O}_{8}$ & fruits & NS & China & [37] \\
\hline Tribulusamide B & $\mathrm{C}_{36} \mathrm{H}_{34} \mathrm{~N}_{2} \mathrm{O}_{9}$ & fruits & NS & China & [37] \\
\hline Tribulusamide D & $\mathrm{C}_{17} \mathrm{H}_{15} \mathrm{NO}_{5}$ & fruits & NS & Korea & [48] \\
\hline Tribulusamide C & $\mathrm{C}_{18} \mathrm{H}_{15} \mathrm{NO}_{6}$ & fruits & NS & China & [49] \\
\hline
\end{tabular}


Table 2. Cont.

\begin{tabular}{|c|c|c|c|c|c|}
\hline Compound & $\begin{array}{l}\text { Chemical } \\
\text { Formula }\end{array}$ & Plant Part & $\begin{array}{c}\text { Conc. } \\
\mathrm{mg} / 100 \mathrm{~g}\end{array}$ & $\begin{array}{l}\text { Plant } \\
\text { Origin }\end{array}$ & References \\
\hline \multicolumn{6}{|c|}{ Fatty Acids and Fatty Acid Esters } \\
\hline Oleic acid & $\mathrm{C}_{18} \mathrm{H}_{34} \mathrm{O}_{2}$ & stem & NS & Pakistan & [50] \\
\hline Palmitic acid & $\mathrm{C}_{16} \mathrm{H}_{32} \mathrm{O}_{2}$ & stem & NS & Pakistan & [50] \\
\hline $\begin{array}{c}\text { 6,9,12,15-Docosatetraenoic acid, } \\
\text { methyl ester }\end{array}$ & $\mathrm{C}_{23} \mathrm{H}_{38} \mathrm{O}_{2}$ & stem & NS & Pakistan & [50] \\
\hline $\begin{array}{l}\text { Pentadecanoic acid, 14-methyl-, } \\
\text { methyl ester }\end{array}$ & $\mathrm{C}_{17} \mathrm{H}_{34} \mathrm{O}_{2}$ & stem & NS & Pakistan & [50] \\
\hline $\begin{array}{l}\text { 9,12-Octadecadienoic acid, methyl } \\
\text { ester }(\mathrm{E}, \mathrm{E}) \text { - }\end{array}$ & $\mathrm{C}_{19} \mathrm{H}_{34} \mathrm{O}_{2}$ & stem & NS & Pakistan & [50] \\
\hline \multicolumn{6}{|c|}{ Phytosterols } \\
\hline$\beta$-sistosterol-D-glucoside & $\mathrm{C}_{35} \mathrm{H}_{60} \mathrm{O}_{6}$ & whole plant & NS & India & [32] \\
\hline Stigmasterol & $\mathrm{C}_{29} \mathrm{H}_{48} \mathrm{O}$ & stem & NS & Pakistan & [50] \\
\hline \multicolumn{6}{|c|}{ Other Compounds } \\
\hline B-1, 5-O-dibenzoyl ribofuranose & $\mathrm{C}_{19} \mathrm{H}_{18} \mathrm{O}_{7}$ & roots & NS & India & [51] \\
\hline $\begin{array}{l}\text { 1,3-Benzenedicarboxylic acid, } \\
\text { bis(2-ethylhexyl) ester }\end{array}$ & $\mathrm{C}_{24} \mathrm{H}_{38} \mathrm{O}_{4}$ & stem & NS & Pakistan & [50] \\
\hline Apiol & $\mathrm{C}_{12} \mathrm{H}_{14} \mathrm{O}_{4}$ & stem & NS & Pakistan & [50] \\
\hline Octacosane & $\mathrm{C}_{28} \mathrm{H}_{58}$ & stem & NS & Pakistan & [50] \\
\hline Heptacosane & $\mathrm{C}_{27} \mathrm{H}_{56}$ & stem & NS & Pakistan & [50] \\
\hline
\end{tabular}

Concentration is expressed in $\mathrm{mg} / 100 \mathrm{~g}$ DW (dry weight). NS, not specified or the concentration could not be calculated using the given data in research paper.

Studies have revealed that the composition is strictly linked with the origin of the plant, and hence with climatic conditions.

Geographical regions significantly influence the composition of herbal drugs. Dinchev et al. [3] detected prototribestin only in the samples collected from Bulgaria, Turkey, Greece, Macedonia, Iran, and Serbia, but no protodioscin was detected in the samples collected from Vietnam and India. It appeared that this compound could be a marker for the European variety of TT [3]. Lazarova et al. [4] demonstrated that there were considerable differences between the samples collected from the same country; dioscin was not detected in some samples collected from Bulgaria, and the concentrations of the compounds also varied widely. The obtained result could be correlated with the methods used for extraction because furostanol bidesmosides were transformed into their spirostanol monodesmosides analogs during extraction. Lazarova et al. [4] performed the extraction by sonication for $15 \mathrm{~min}$, using 50\% aqueous acetonitrile as a solvent, but as shown by Sarvin et al. [18], a longer extraction time (60 min) gave a better yield. The $\beta$-Carboline indole alkaloids, i.e., harman, harmine, and harmalol were isolated from fruits, leaves, stems, and roots, but harmaline was only isolated from the roots, stem, and leaves [44]. As can be seen in Table 2, the concentration of protodioscin, prototribestin, dioscin, tribestin, and tribulosin varies within very wide limits depending on the origin of the plant. Differences are noticed between the different organs of the plant. These significant variations in TT composition explain the opposite pharmacological effects obtained in the performed studies. In Figure 2 are presented the chemical structures of the main compounds found in TT, other than the steroidal compounds. 
<smiles>O=c1c(O)c(-c2ccc(O)cc2)oc2cc(O)cc(O)c12</smiles>

(a) Kaempferol<smiles>O=C(/C=C\c1ccc(O)cc1)OC[C@H]1O[C@@H](Oc2c(-c3ccc(O)cc3)oc3cc(O)cc(O)c3c2=O)[C@H](O)[C@@H](O)[C@@H]1O</smiles>

(c) Tribuloside<smiles>C[C@H]1O[C@H](OC[C@H]2OC(Oc3c(-c4ccc(O)c(O)c4)oc4cc(O)cc(O)c4c3=O)[C@H](O)[C@@H](O)[C@@H]2O)[C@H](O)[C@@H](O)[C@@H]1O</smiles>

(e) Rutin<smiles>O=c1c(OC2OC3C(O)C(O)C(O)C(O)C3O2)c(-c2ccc(O)cc2)oc2cc(O)cc(O)c12</smiles>

(b) Astragalin<smiles>C[C@H]1O[C@H](OC[C@H]2OC(Oc3c(-c4ccc(O)cc4)oc4cc(O)cc(O)c4c3=O)[C@H](O)[C@@H](O)[C@@H]2O)[C@H](O)[C@@H](O)[C@@H]1O</smiles>

(d) Kaempferol 3-rutinoside<smiles>O=c1c(O)c(-c2ccc(O)c(O)c2)oc2cc(O)cc(O)c12</smiles>

(f) Quercetin

Figure 2. Cont. 
<smiles>Cc1nccc2c1[nH]c1ccccc12</smiles>

(g) Harmane<smiles>O=C(/C=C/c1ccc(O)cc1)NCCc1ccc(O)cc1</smiles>

(h) Coumaroyltyramine<smiles>COc1cc(/C=C/C(=O)O)ccc1O</smiles>

(j) Ferulic acid

(i) Caffeoyltyramine<smiles>COc1cc(/C=C/C(=O)NCCc2ccc(O)cc2)ccc1O</smiles>

(k) Feruloyloctopamine<smiles>O=C(/C=C/c1ccc(O)cc1)O[C@@H]1C[C@](O)(C(=O)O)C[C@H](O)[C@H]1O</smiles>

(i) 5-p-trans-coumaroylquinic acid<smiles>O=C(/C=C\c1ccc(O)cc1)O[C@H]1C[C@@](O)(C(=O)O)C[C@H](O)[C@H]1O</smiles>

(m) 5-p-cis-coumaroylquinic acid

Figure 2. The most common compounds found in TT extracts.

\section{Pharmacological Properties}

\subsection{Pharmacokinetic Properties of TT Main Compounds}

Protodioscin is the dominant component in TT fruits and is considered to be the main pharmacologically active steroidal saponin [3]. Studies regarding the pharmacokinetic characteristics of protodioscin have contradictory results. For example, a recent study published by Zhang et al. [52] concluded that protodioscin had low bioavailability in vivo. However, the same group of authors has shown that after the administration of an extract from Dioscorea, the pharmacokinetic profile of protodioscin revealed good bioavailability [53]. Despite multiple in vivo studies with TT, very little is known about the pharmacokinetics of the therapeutically active compounds. There are, however, pharmacokinetic studies for protodioscin and dioscin after the administration of different Dioscorea sp. extracts $[53,54]$. Saponins, due to their amphiphilic molecule, have membrane permeabilizing properties, thus, they could increase the absorption of other compounds. This property is of great importance because toxic effects could appear in patients with multiple conditions who undergo chronic treatments.

\subsection{Antioxidant Activity}

Production of reactive oxygen species (ROS) in the body and their correlation with the incidence of chronic diseases has been largely described in the scientific literature and is already a fact. 
TT extracts contain flavonoids and polyphenol carboxylic acids. The antioxidant activity of these compounds has been convincingly confirmed, based on their ability to donate hydrogen. Polyphenols are capable of scavenging hydroxyl $\left(\mathrm{HO}^{\bullet}\right)$, peroxyl $\left(\mathrm{RO}_{2}^{\bullet}\right)$, and superoxide $\left(\mathrm{O}_{2}^{\bullet-}\right)$ radicals [55].

$$
\mathrm{O}_{2} \rightarrow \mathrm{O}^{\bullet}{ }_{2}^{-} \rightarrow \mathrm{H}_{2} \mathrm{O}_{2} \rightarrow \mathrm{HO}^{\bullet}+\mathrm{HO}^{-} \rightarrow 2 \mathrm{H}_{2} \mathrm{O}
$$

Nevertheless, the effect of flavonoids varies and is strictly linked to their chemical characteristics and functional groups. Lower scavenging effects were noticed on singlet oxygen, and only for flavonones and phenolic acids [56]. In vitro determinations have proven that TT extracts have antioxidant activity determined using DPPH, ABTS, and FRAP methods. The reported concentration of polyphenols ranges from $0.6 \%$ to $3 \%$ and the content in flavonoids ranges from $0.04 \%$ to $0.5 \%$ [57,58]. It has been shown that when fractionated extracts were tested for their antioxidant activity, the ethyl acetate fraction had the strongest DPPH free radical scavenging activity, and the responsible compounds from this fraction were 4,5-di-p-cis-coumaroylquinic acid, and 4,5-di-p-trans-coumaroylquinic acid [27].

Dutt-Roy et al. [59] observed in an in vivo study that the treatment with TT extracts (part of the plant not specified, ethanol extraction, origin India) increased the activities of catalase and superoxide dismutase, and decreased the malondialdehyde (MDA) concentration. These effects were noticed in diabetic rats and in rats with depression induced by para-chlorophenylalanine (a selective and irreversible inhibitor of tryptophan hydroxylase) [59]. Catalase breaks down hydrogen peroxide $\left(\mathrm{H}_{2} \mathrm{O}_{2}\right)$ to water and oxygen, and it has an essential role in the protection of cells from ROS. Superoxide dismutase catalyzes the transformation of superoxide anion free radical $\left(\mathrm{O}_{2}{ }^{-}\right)$into oxygen $\left(\mathrm{O}_{2}\right)$ and $\mathrm{H}_{2} \mathrm{O}_{2}$ [60]. MDA is a marker of oxidative stress and is one of the final products of polyunsaturated fatty acids (PUFAs) peroxidation [61].

Studies have shown that STZ-induced diabetes increased oxidative stress, and apparently, TT extracts (plant origin UAE, 70\% ethanolic extract) were capable of modulating oxidative stress markers (MDA and GSH) [62].

\subsection{Sexual Disorders}

On the basis of the widespread societal presumption that natural compounds are active in erectile dysfunction, but lack the side effects specific to compounds obtained by chemical synthesis (e.g., phosphodiesterase- 5 inhibitors such as sildenafil, tadalafil, etc.), they are often preferred and used for extended periods. Various products containing TT extracts are widely utilized for this purpose, mainly due to the advertising of supplements for professional athletes, based on the alleged effect of testosterone boosting. Existing data in the literature, resulting from in vitro experiments, by analyzing animal models (preclinical studies) and evaluating endpoints from clinical trials on subjects with erectile dysfunction are presented below.

\subsubsection{In Vitro Experiments}

The main objective of in vitro studies was to evaluate the quality of semen (morphology and viability). In vitro incubation of human spermatozoa with TT extract (origin Iran, part of the plant used not specified, extraction with water) had a beneficial effect on motility and viability. These findings suggest that TT extracts could be further used in the preparation of spermatozoa before in vitro fertilization [63]. An organ bath study of the corpus cavernosum (CC) from rabbits showed that TT extract (origin Korea) produced a concentration-dependent relaxation response. The authors suggested that because the location of action was in the endothelium, the relaxation effect appeared via the NOS pathway [64].

\subsubsection{Preclinical Experimental Studies (Animal Models)}

Preclinical studies have focused on animal models of human diseases that affect spermatogenesis and androgen secretion (cytotoxic medication that affects the gonads, castration, and diabetes); the effect 
of TT extracts on spermatogenesis and gonadal steroidogenesis in healthy male subjects, whether or not subjected to standardized physical exertion has also been evaluated.

In adult male Swiss albino mice with reproductive damage induced by cyclophosphamide, TT showed an improvement of epididymal sperm characteristics (motility) and an increase in testosterone levels as compared with the control group [65]. Extracts with TT administered to trained rats (fruit extract, China $>70 \%$ saponins), diabetic rats (seed extract, Iran), healthy male rats (flowers, Iran) led to a significant increase in testosterone levels as compared with the control [66-68]. In healthy Wistar rats, a 70-day supplementation with TT extract influenced spermatogenesis, as shown by the changes in the tubular compartment of the testes (increase in the total tube length, tubular volume, and height of the seminiferous epithelium) [69]. In healthy male rats, a significantly increased testosterone level was confirmed as compared with the control group and positive effects on sexual parameters [68]. The TT extracts (origin Bulgaria) improved sexual behavior in castrated rats (mount frequency, intromission frequency, mount latency, intromission latency, ejaculation latency, and post-ejaculatory interval) [70].

\subsubsection{Clinical Trials}

The analysis of available clinical trials on the effectiveness of TT extracts in men highlights two categories of primary endpoints as follows: Some studies set as their main goal the evaluation of efficacy in erectile dysfunction (erection quality and libido intensity) and others evaluated the change in the basal secretion of testosterone at the end of the study with the initial values of the subjects serving as the control. However, the available studies did not shed light on the controversy regarding the real efficacy of TT. On the one hand, due to the divergent results (when the quantified parameter could be determined accurately such as testosterone and dihydrotestosterone, pituitary gonadotropin levels, etc.); on the other hand, due to the subjective evaluation (especially if the endpoints were based on the self-evaluation of the subjects' standardized questionnaires such as the International Index of Erectile Function (IIEF), Questionnaire and Global Efficacy Question (GEQ).

Recently, Kamenov et al. [71] evaluated the efficacy and safety of a standardized extract (Tribestan ${ }^{\circledR}$, Sopharma AD-coated tablets containing $250 \mathrm{mg}$ of dry extract equivalent to furostanol saponins not less than $112.5 \mathrm{mg}$ ) for the treatment of men with mild to moderate erectile dysfunction and with or without hypoactive sexual desire disorder in a prospective, phase IV, randomized, double-blind, placebo controlled clinical trial in parallel groups. The characteristics of the study can be summarized as follows: dose of three coated tablets per day; sample size of 90 subjects in each group (treated vs. placebo); duration of 12 weeks; primary endpoint, the change in IIEF score at the end of the treatment. The authors showed a significant improvement in erection, libido, and orgasmic function in the treated group, in the absence of any difference in the profile of side effects as compared with the placebo [71].

Santos et al. [72] conducted a prospective, randomized, double-blind study on patients with erectile dysfunction. The treated group received $400 \mathrm{mg}$ of TT extract. There were no significant differences noticed between the placebo and the treated group. The origin of the plant or the method of extraction were not specified.

In contrast to these data, two studies confirmed the beneficial effects after treatment with pharmaceutical products containing TT and other components. The first study showed that after 20 days of supplementation with the dietary supplement "Tribulus", anaerobic muscle power and serum testosterone increased significantly in young men [73]. The other double-blind placebo controlled study in older men with a history of erectile dysfunction and lower levels of total and free testosterone showed high efficacy of a preparation containing TT. The product, called "Tradamixin", consisted of TT, Alga Eckonia, D-glucosamine, and N-acetyl-glucosamine, was given daily for two months, and improved libido in elderly men and increased testosterone. It should be noted, however, that in both experiments, there was no certainty that a particular component would have caused those biological benefits or if TT contributed to those effects [74].

In a study conducted on male boxers, the administration of a TT supplement (with $>40 \%$ saponins) produced no effect on plasma testosterone and dihydrotestosterone. Although the results were 
inconclusive, the authors suggested that a possible mechanism of action for TT compounds could be related to insulin-like growth factor (IGF-1) and insulin-like growth factor binding protein 3 (IGFBP-3). IGF-1 is a growth hormone that showed the capacity of elevating skeletal muscles and preventing age-related loss of muscle mass [35].

Additionally, IGF improves insulin signaling, which could explain the beneficial effects obtained with TT extracts in diabetes, but the exact mechanism of action is not fully known [75].

The booster effects of TT extracts have been confirmed by some authors, both in experimental research and in clinical studies, as shown above, but are questioned by others. The available data on the mechanisms underlying the use in sexual disorders can be summarized as follows (Figure 3): steroidal saponins from TT increase the endogenous testosterone levels, due to an indirect action, i.e., the LH-type action of the steroidal saponosides or a weak androgenic agonist type action [13], but these mechanisms are denied by others [76,77]. Luteinizing hormone (LH) regulates the expression of $17 \beta$-hydroxysteroid dehydrogenase, which is the enzyme that transforms androstenedione into testosterone [78]. In addition, the antioxidant effect could contribute to the booster action of TT, knowing that oxidative stress is linked to endothelial dysfunction. Nitric oxide mediates the formation of cyclic guanosine monophosphate (cGMP); this mechanism could promote erection by vasodilation and increased blood supply to the corpora cavernosa [64,79]. In oxidative stress, the reactive oxygen species and advanced end glycation products react with nitric oxide in the vasculature forming reactive nitrogen species, contributing to the pathogenesis of erectile dysfunction [80]. Furthermore, different studies have shown that TT extracts are efficient in women with sexual disorders by having a favorable action in clinical trials on hypoactive sexual desire in women, as well as in the control of menopausal transition symptoms [81-83].

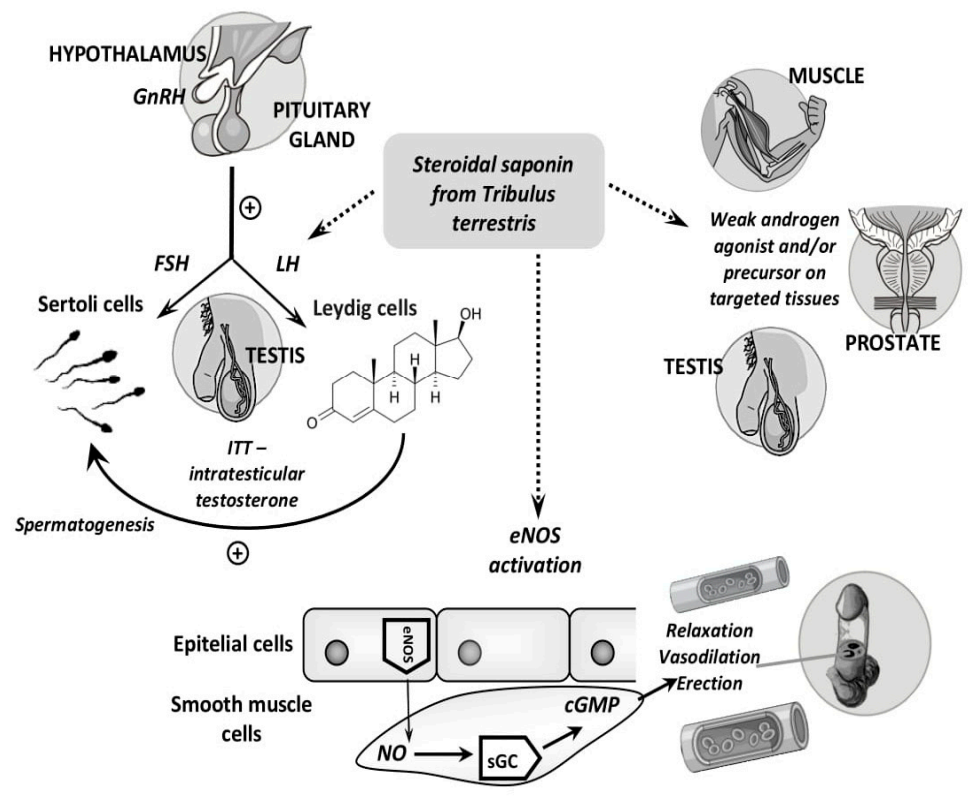

Figure 3. The presumed mechanisms of action responsible for the effects of TT extracts in sexual disorders. GnRH, gonadotropin-releasing hormone; FSH, follicle-stimulating hormone; LH, luteinizing hormone; ITT, intratesticular testosterone; eNOS, endothelial nitric oxide synthase; NO, nitric oxide; sGC, soluble guanylate cyclase; and cGMP, cyclic guanosine monophosphate.

Given the testosterone boosting action of the extract, research has been performed to evaluate if the consumption of TT extracts could influence the doping tests of athletes regarding the urinary testosterone/epitestosterone TS/ET ratio limit of 4:1 (World Anti-Doping Agency) [84].

The in vitro and in vivo studies are briefly presented in Table 3, where pharmacological actions related to sexual disorders have been evaluated. 
Table 3. In vitro and in vivo studies regarding the efficacy of TT extracts in sexual disorders and their design evaluation.

\begin{tabular}{|c|c|c|c|c|}
\hline $\begin{array}{l}\text { Herbal Drug and } \\
\text { Subjects }\end{array}$ & Assay/Parameters & $\begin{array}{c}\text { Outcome of Treated } \\
\text { Group }\end{array}$ & $\begin{array}{l}\text { Study Design } \\
\text { Evaluation }\end{array}$ & Reference \\
\hline \multicolumn{5}{|c|}{ In Vitro Studies } \\
\hline $\begin{array}{l}\text { Organ bath study of } \\
\text { the corpus cavernosum }\end{array}$ & & & $\begin{array}{c}\text { Part of the plant: } \\
\text { NO }\end{array}$ & $\begin{array}{l}\text { Kam et al. } \\
\quad(2012)\end{array}$ \\
\hline $\begin{array}{l}\text { from } \\
\text { male rabbits }\end{array}$ & Relaxation level & $\begin{array}{l}\text { Concentration-dependent } \\
\text { relaxation response }\end{array}$ & $\begin{array}{l}\text { Origin: NO } \\
\text { Phytochemical } \\
\text { analysis: NO }\end{array}$ & [64] \\
\hline & & & Control group: NO & \\
\hline & & & Appropriate & \\
\hline & & & $\begin{array}{c}\text { Statistical analysis: } \\
\text { YES }\end{array}$ & \\
\hline $\begin{array}{c}\text { Human sperm from } 40 \\
\text { healthy volunteers }\end{array}$ & Motility analysis & $\begin{array}{c}\text { Motility } \uparrow * \text { after } 60 \\
\text { minutes of incubation } \\
\text { Viability } \uparrow * \text { in a }\end{array}$ & $\begin{array}{c}\text { Part of the plant: } \\
\text { NO }\end{array}$ & $\begin{array}{l}\text { Khaleghi et al. } \\
\text { (2017) }\end{array}$ \\
\hline \multirow[t]{3}{*}{ TT extract } & $\begin{array}{l}\text { Sperm viability } \\
\text { analysis }\end{array}$ & $\begin{array}{l}\text { dose-dependent manner } \\
\text { after } 120 \text { minutes of } \\
\text { incubation }\end{array}$ & Origin: YES & [63] \\
\hline & $\begin{array}{l}\text { Determination of } \\
\text { DNA }\end{array}$ & $\begin{array}{l}\text { No effect on DNA } \\
\text { fragmentation of human } \\
\text { sperm in vitro }\end{array}$ & $\begin{array}{l}\text { Phytochemical } \\
\text { analysis: NO }\end{array}$ & \\
\hline & & & $\begin{array}{l}\text { Control group: YES } \\
\text { Appropriate } \\
\text { statistical analysis: } \\
\text { YES }\end{array}$ & \\
\hline \multicolumn{5}{|c|}{ In Vivo Animal Studies } \\
\hline $\begin{array}{c}\text { Male adult Sprague } \\
\text { Dawley rats, castrated } \\
\text { and normal }\end{array}$ & $\begin{array}{l}\text { Sexual behavior } \\
\text { studies: MF, IF, ML, } \\
\text { IL, EL, PEI }\end{array}$ & $\begin{array}{l}\text { Treatment of castrated } \\
\text { rats (with testosterone or } \\
\text { TT extract) showed } \\
\text { increase in prostate } \\
\text { weight and ICP that were } \\
\text { statistically significant } \\
\text { Mild to moderate }\end{array}$ & $\begin{array}{c}\text { Part of the plant: } \\
\text { NCS }\end{array}$ & $\begin{array}{l}\text { Gauthaman et } \\
\text { al. (2002) }\end{array}$ \\
\hline \multirow[t]{2}{*}{ TT extract } & ICP & $\begin{array}{l}\text { improvement of sexual } \\
\text { behavior parameters }\end{array}$ & Origin: YES & [70] \\
\hline & & & $\begin{array}{l}\text { Phytochemical } \\
\text { analysis: NCS } \\
\text { Control group: YES } \\
\text { Positive control } \\
\text { group: YES } \\
\text { Appropriate } \\
\text { statistical analysis: } \\
\text { YES }\end{array}$ & \\
\hline $\begin{array}{l}\text { Male Sprague Dawley } \\
\text { rats }\end{array}$ & ICP & $\begin{array}{c}\text { ICP } \\
\text { concentration-dependent } \\
\text { increase in TT treated } \\
\text { group* }\end{array}$ & $\begin{array}{c}\text { Part of the plant: } \\
\text { NCS }\end{array}$ & $\begin{array}{l}\text { Kam et al. } \\
\text { (2012) }\end{array}$ \\
\hline \multirow[t]{3}{*}{$\begin{array}{l}\text { TT extract, Cornus } \\
\text { officinalis extract and a } \\
\text { mixture of both }\end{array}$} & $\begin{array}{l}\text { cAMP, cGMP in } \\
\text { corpus cavernosum }\end{array}$ & $\begin{array}{l}\text { cAMP } \uparrow^{*} \text { in the group } \\
\text { treated with the mixture }\end{array}$ & Origin: YES & [64] \\
\hline & & $\begin{array}{l}\text { cGMP no significant } \\
\text { difference as compared } \\
\text { with the control }\end{array}$ & $\begin{array}{c}\text { Phytochemical } \\
\text { analysis: NO }\end{array}$ & \\
\hline & & & $\begin{array}{l}\text { Control group: YES } \\
\text { Positive control } \\
\text { group: NO } \\
\text { Appropriate } \\
\text { statistical analysis: } \\
\text { YES }\end{array}$ & \\
\hline
\end{tabular}


Table 3. Cont.

\begin{tabular}{|c|c|c|c|c|}
\hline $\begin{array}{l}\text { Herbal Drug and } \\
\text { Subjects }\end{array}$ & Assay/Parameters & $\begin{array}{c}\text { Outcome of Treated } \\
\text { Group }\end{array}$ & $\begin{array}{l}\text { Study Design } \\
\text { Evaluation }\end{array}$ & Reference \\
\hline -Male rats & $\begin{array}{l}\text { Morphometric } \\
\text { analysis }\end{array}$ & Testicular weight $\uparrow^{*}$ & Origin: YES & $\begin{array}{l}\text { Oliveira et al. } \\
\qquad(2015)\end{array}$ \\
\hline \multirow[t]{4}{*}{$\begin{array}{l}\text { TT fruit extract and } \\
\text { fractions }\end{array}$} & $\begin{array}{l}\text { Gonadosomatic } \\
\text { index }\end{array}$ & $\begin{array}{l}\text { Gonadosomatic index } \\
\text { increased in the group } \\
\text { supplemented with } \\
\text { ethanolic extract } \\
\text {-Nuclear, cytoplasmic, } \\
\text { and individual volume }\end{array}$ & $\begin{array}{c}\text { Part of the plant: } \\
\text { YES }\end{array}$ & [69] \\
\hline & $\begin{array}{l}\text { Sperm quality } \\
\text { analysis: motility, }\end{array}$ & $\begin{array}{l}\text { of Leydig cells increased } \\
\text { in supplementation with } \\
\text { hexanic and aqueous } \\
\text { fractions }\end{array}$ & $\begin{array}{l}\text { Phytochemical } \\
\text { analysis: NO }\end{array}$ & \\
\hline & sperm count, & $\begin{array}{l}\text { The extract influenced } \\
\text { the spermatogenesis }\end{array}$ & Control group: YES & \\
\hline & $\begin{array}{l}\text { morphology, } \\
\text { viability }\end{array}$ & & $\begin{array}{l}\text { Positive control } \\
\text { group: NO } \\
\text { Appropriate } \\
\text { statistical analysis: } \\
\text { YES }\end{array}$ & \\
\hline $\begin{array}{c}\text { Male Wistar rats with } \\
\text { STZ-induced diabetes } \\
\qquad(55 \mathrm{mg} / \mathrm{kg})\end{array}$ & $\begin{array}{c}\text { Sperm } \\
\text { characteristics, } \\
\text { morphology }\end{array}$ & $\begin{array}{l}\text { TT restored antioxidant } \\
\text { enzyme activity in testis }\end{array}$ & $\begin{array}{c}\text { Part of the plant: } \\
\text { YES }\end{array}$ & Tag et al. (2015) \\
\hline \multirow[t]{5}{*}{ TT fruit extract } & $\begin{array}{l}\text { Body and genital } \\
\text { organ weight }\end{array}$ & $\begin{array}{l}\text { Improved lipid profile } \\
\text { content in serum }\end{array}$ & Origin: YES & [85] \\
\hline & $\begin{array}{l}\text { Serum testosterone, } \\
\text { FSH, LPO level in } \\
\text { testicular } \\
\text { homogenate }\end{array}$ & $\begin{array}{l}\text { TT treatment decreased } \\
\text { testis tubular damage } \\
\text { and restored it to normal } \\
\text { morphology. }\end{array}$ & $\begin{array}{l}\text { Phytochemical } \\
\text { analysis: YES } \\
\text { (identification } \\
\text { reactions) }\end{array}$ & \\
\hline & $\begin{array}{l}\text { Activity of } \\
\text { testicular SOD }\end{array}$ & & Control group: YES & \\
\hline & $\begin{array}{l}\text { Testicular CAT } \\
\text { activity }\end{array}$ & & $\begin{array}{l}\text { Positive control } \\
\text { group: YES } \\
\text { Appropriate }\end{array}$ & \\
\hline & GPx, GST & & $\begin{array}{c}\text { statistical analysis: } \\
\text { YES }\end{array}$ & \\
\hline $\begin{array}{l}\text { Male Wistar rats with } \\
\text { STZ-induced diabetes } \\
\qquad(50 \mathrm{mg} / \mathrm{kg})\end{array}$ & Testosterone & $\begin{array}{l}\text { Sperm motility, sperm } \\
\text { count, percentage of } \\
\text { sperms with normal } \\
\text { morphology } \uparrow^{*}\end{array}$ & $\begin{array}{c}\text { Part of the plant: } \\
\text { YES }\end{array}$ & $\begin{array}{c}\text { Ghanbari et al. } \\
\text { (2016) }\end{array}$ \\
\hline \multirow[t]{3}{*}{ TT seed extract } & $\begin{array}{l}\text { Sperm analysis: } \\
\text { morphology, count } \\
\text { and motility }\end{array}$ & Testosterone $\uparrow^{*}$ & Origin: NO & [67] \\
\hline & & & $\begin{array}{l}\text { Phytochemical } \\
\text { analysis: NO }\end{array}$ & \\
\hline & & & $\begin{array}{l}\text { Control group: YES } \\
\text { Positive control } \\
\text { group: NO } \\
\text { Appropriate } \\
\text { statistical analysis: } \\
\text { YES }\end{array}$ & \\
\hline $\begin{array}{l}\text { Male Sprague Dawley } \\
\text { rats }\end{array}$ & $\begin{array}{l}\text { Time to exhaustion } \\
\text { of over trained rats }\end{array}$ & $\begin{array}{l}\text { Performance (time to } \\
\text { exhaustion) } \uparrow^{*}\end{array}$ & Origin: YES & Yin et al. (2016) \\
\hline \multirow[t]{4}{*}{$\begin{array}{l}\text { TT fruit extract } \\
\text { (saponins }>70 \% \text { ) }\end{array}$} & $\begin{array}{c}\text { Serum testosterone, } \\
\text { corticosterone, AR, } \\
\text { IGF-1R in liver, } \\
\text { gastrocnemius, and } \\
\text { soleus }\end{array}$ & $\begin{array}{l}\text { Increase in body weights, } \\
\text { relative weights, and } \\
\text { protein levels of } \\
\text { gastrocnemius }\end{array}$ & $\begin{array}{c}\text { Part of the plant: } \\
\text { YES }\end{array}$ & [66] \\
\hline & & Testosterone $\uparrow^{*}$ & $\begin{array}{l}\text { Phytochemical } \\
\text { analysis: YES } \\
\text { (UHPLC-Q-TOF/MS) }\end{array}$ & \\
\hline & & $\mathrm{AR} \uparrow^{*}$ & $\begin{array}{l}\text { Control group: YES } \\
\text { Appropriate }\end{array}$ & \\
\hline & & IGF-1R $\downarrow \#$ & $\begin{array}{c}\text { Statistical analysis: } \\
\text { YES }\end{array}$ & \\
\hline
\end{tabular}


Table 3. Cont.

\begin{tabular}{|c|c|c|c|c|}
\hline $\begin{array}{l}\text { Herbal Drug and } \\
\text { Subjects }\end{array}$ & Assay/Parameters & $\begin{array}{c}\text { Outcome of Treated } \\
\text { Group }\end{array}$ & $\begin{array}{l}\text { Study Design } \\
\text { Evaluation }\end{array}$ & Reference \\
\hline $\begin{array}{l}\text { Adult male Swiss } \\
\text { albino mice }\end{array}$ & SOD, CAT, GPx, & SOD, CAT, GST $\downarrow \#$ & $\begin{array}{c}\text { Part of the plant: } \\
\text { YES }\end{array}$ & $\begin{array}{l}\text { Pavin et al. } \\
\quad(2018)\end{array}$ \\
\hline \multirow[t]{5}{*}{ TT fruit extract } & $\begin{array}{c}\text { GR, GST, GSH, } \\
17 \beta-H S D\end{array}$ & GPx $\uparrow \#$ & Origin: YES & [65] \\
\hline & $\begin{array}{l}\text { Plasma } \\
\text { testosterone }\end{array}$ & $\begin{array}{l}17 \beta-H S D \text { activity in } \\
\text { treated group was not } \\
\text { statistically significant } \\
\text { different as compared } \\
\text { with the control group }\end{array}$ & $\begin{array}{l}\text { Phytochemical } \\
\text { analysis: YES } \\
\text { (UHPLC-Q-TOF/MS) }\end{array}$ & \\
\hline & Semen analysis: & Testosterone $\uparrow$ & Control group: YES & \\
\hline & $\begin{array}{l}\text { motility, vigor, } \\
\text { membrane } \\
\text { integrity }\end{array}$ & Motility $\uparrow \#$ & $\begin{array}{l}\text { Positive control } \\
\text { group: YES }\end{array}$ & \\
\hline & Histology of testes & $\begin{array}{l}\text { No significant } \\
\text { modifications in } \\
\text { testicular architecture }\end{array}$ & $\begin{array}{c}\text { Appropriate } \\
\text { statistical analysis: } \\
\text { YES }\end{array}$ & \\
\hline Male Wistar rats & $\begin{array}{l}\text { Sperm analysis: } \\
\text { sperm count, } \\
\text { viability, motility }\end{array}$ & Testosterone, LH $\uparrow^{*}$ & $\begin{array}{c}\text { Part of the plant: } \\
\text { YES }\end{array}$ & Haghmorad \\
\hline TT flower extract and & $\begin{array}{l}\text { Serum testosterone, } \\
\text { LH, FSH levels }\end{array}$ & $\begin{array}{l}\text { All the treatment groups } \\
\text { had higher number of } \\
\text { Leydig, spermatogonia } \\
\text { and spermatid cells }\end{array}$ & Origin: YES & et al. (2019) \\
\hline \multirow[t]{2}{*}{$\begin{array}{l}\text { Anacyclus Pyrethrum } \\
\text { dried root extract }\end{array}$} & $\begin{array}{l}\text { Histological } \\
\text { analysis of Leydig } \\
\text { and Sertoli cells, } \\
\text { spermatogonia, } \\
\text { and spermatid cell } \\
\text { numbers measure }\end{array}$ & & $\begin{array}{l}\text { Phytochemical } \\
\text { analysis: NO }\end{array}$ & [68] \\
\hline & & & $\begin{array}{l}\text { Control group: YES } \\
\text { Positive control } \\
\text { group: NO } \\
\text { Appropriate } \\
\text { statistical analysis: } \\
\text { YES }\end{array}$ & \\
\hline $\begin{array}{l}\text { Sprague Dawley rats } \\
\text { with type } 2 \text { diabetes } \\
\text { induced with high-fat } \\
\text { and high-sugar feeding } \\
\text { and STZ }(30 \mathrm{mg} / \mathrm{kg})\end{array}$ & ICP, MAP & ICP, ICP/MAP $\uparrow *$ & $\begin{array}{l}\text { Part of the plant: } \\
\text { NCS }\end{array}$ & $\begin{array}{l}\text { Zhang et al. } \\
\text { (2019) }\end{array}$ \\
\hline \multirow[t]{4}{*}{$\begin{array}{c}\text { Gross saponins of TT } \\
\text { (GSTT) }\end{array}$} & $\begin{array}{c}\text { eNOS expression } \\
\text { level }\end{array}$ & Nitric oxide $\uparrow^{*}$ & Origin: YES & [86] \\
\hline & Nitric oxide level & $\operatorname{ROS} \downarrow^{*}$ & $\begin{array}{l}\text { Phytochemical } \\
\text { analysis: NCS }\end{array}$ & \\
\hline & $\begin{array}{c}\text { cAMP expression } \\
\text { level }\end{array}$ & $\begin{array}{c}\text { No significant difference } \\
\text { between the GSTT group } \\
\text { and the sildenafil group } \\
\text { in increasing cGMP } \\
\text { levels }\end{array}$ & Control group: YES & \\
\hline & ROS levels & & $\begin{array}{c}\text { Positive control } \\
\text { group: YES } \\
\text { Appropriate } \\
\text { statistical analysis: } \\
\text { YES }\end{array}$ & \\
\hline
\end{tabular}


Table 3. Cont.

\begin{tabular}{|c|c|c|c|c|}
\hline $\begin{array}{l}\text { Herbal Drug and } \\
\text { Subjects }\end{array}$ & Assay/Parameters & $\begin{array}{c}\text { Outcome of Treated } \\
\text { Group }\end{array}$ & $\begin{array}{l}\text { Study Design } \\
\text { Evaluation }\end{array}$ & Reference \\
\hline \multicolumn{5}{|c|}{ Clinical Studies } \\
\hline \multirow[t]{3}{*}{$\begin{array}{c}\text { 20-36-Year-old men } \\
\text { TT extract }\end{array}$} & $\begin{array}{c}\text { Testosterone, } \\
\text { androstenedione, } \\
\text { LH levels in the } \\
\text { serum were } \\
\text { measured before } \\
\text { and after treatment } \\
(24,72,240,408, \\
\text { and } 576 \mathrm{~h})\end{array}$ & $\begin{array}{c}\text { No significant difference } \\
\text { between TT } \\
\text { supplemented groups } \\
\text { and the control in the } \\
\text { serum testosterone, } \\
\text { androstenedione, and } \\
\text { LH }\end{array}$ & $\begin{array}{c}\text { Part of the plant: } \\
\text { YES } \\
\text { Origin: YES } \\
\text { Phytochemical } \\
\text { analysis or } \\
\text { standardization: } \\
\text { YES } \\
\text { Placebo group: } \\
\text { YES } \\
\text { Randomization: } \\
\text { YES } \\
\text { Double-blind: NCS } \\
\text { Appropriate } \\
\text { statistical analysis: } \\
\text { YES }\end{array}$ & $\begin{array}{l}\text { Neychev and } \\
\text { Mitev (2005) } \\
\text { [76] }\end{array}$ \\
\hline & $\begin{array}{c}\text { Strength, fat free } \\
\text { mass }\end{array}$ & No significant changes & $\begin{array}{c}\text { Part of the plant: } \\
\text { NCS }\end{array}$ & $\begin{array}{c}\text { Rogerson et al. } \\
\text { (2007) }\end{array}$ \\
\hline & Urinary $\mathrm{T} / \mathrm{E}$ ratio & $\begin{array}{c}\text { No changes in urinary } \\
\text { T/E ratio }\end{array}$ & Origin: YES & [77] \\
\hline rugby league players & & & $\begin{array}{c}\text { Phytochemical } \\
\text { analysis or } \\
\text { standardization: } \\
\text { YES } \\
\text { Placebo group: } \\
\text { YES } \\
\text { Randomization: } \\
\text { YES } \\
\text { Double-blind: YES } \\
\text { Appropriate } \\
\text { statistical analysis: } \\
\text { YES }\end{array}$ & \\
\hline 20-22-Year-old athletes & $\mathrm{CK}$, testosterone & $\mathrm{CK} \uparrow^{*}$ & $\begin{array}{c}\text { Part of the plant: } \\
\text { NCS }\end{array}$ & $\begin{array}{l}\text { Milasius et al. } \\
\text { (2009) }\end{array}$ \\
\hline \multirow[t]{4}{*}{ TT capsules } & $\begin{array}{l}\text { Anaerobic alactic } \\
\text { muscular power }\end{array}$ & $\begin{array}{l}\text { Testosterone } \uparrow^{*} \text { during } \\
\text { the first half }(10 \text { days }) \text { of } \\
\text { the experiment }\end{array}$ & Origin: NCS & [73] \\
\hline & $\begin{array}{l}\text { Anaerobic alactic } \\
\text { glycolytic power }\end{array}$ & $\begin{array}{l}\text { Anaerobic alactic } \\
\text { muscular power } \uparrow^{*}\end{array}$ & $\begin{array}{c}\text { Phytochemical } \\
\text { analysis or } \\
\text { standardization: } \\
\text { NCS }\end{array}$ & \\
\hline & & $\begin{array}{l}\text { Anaerobic alactic } \\
\text { glycolytic power } \uparrow^{*}\end{array}$ & $\begin{array}{c}\text { Placebo group: } \\
\text { YES }\end{array}$ & \\
\hline & & & $\begin{array}{c}\text { Randomization: } \\
\text { NO } \\
\text { Double-blind: NO } \\
\text { Appropriate } \\
\text { statistical analysis: } \\
\text { YES }\end{array}$ & \\
\hline $\begin{array}{l}\text { Double-blind, } \\
\text { randomized trial }\end{array}$ & IIEF, SQolM, & $\operatorname{IIEF} \uparrow^{*}$ & $\begin{array}{c}\text { Part of the plant: } \\
\text { NCS }\end{array}$ & $\begin{array}{l}\text { Iacono et al. } \\
\text { (2012) }\end{array}$ \\
\hline $\begin{array}{c}\text { Male patients > sixty } \\
\text { years with }\end{array}$ & $\begin{array}{l}\text { Testosterone levels } \\
\text { after } 60 \text { days of } \\
\text { treatment, }\end{array}$ & SQolM $\uparrow^{*}$ & Origin: NCS & [74] \\
\hline $\begin{array}{l}\text { reduced libido, with or } \\
\text { without erectile } \\
\text { dysfunction (ED) }\end{array}$ & Side effects & TT level increased & $\begin{array}{l}\text { Phytochemical } \\
\text { analysis or } \\
\text { standardization: } \\
\text { NCS }\end{array}$ & \\
\hline
\end{tabular}


Table 3. Cont.

\begin{tabular}{|c|c|c|c|c|}
\hline $\begin{array}{l}\text { Herbal Drug and } \\
\text { Subjects }\end{array}$ & Assay/Parameters & $\begin{array}{c}\text { Outcome of Treated } \\
\text { Group }\end{array}$ & $\begin{array}{l}\text { Study Design } \\
\text { Evaluation }\end{array}$ & Reference \\
\hline $\begin{array}{l}\text { Treatment with } \\
\text { "Tradamixina", } \\
\text { tadalafil }\end{array}$ & & $\begin{array}{l}\text { No side effects } \\
\text { (headache, } \\
\text { nasopharyngitis, } \\
\text { back pain, } \\
\text { dizziness, } \\
\text { dyspepsia) were } \\
\text { observed }\end{array}$ & $\begin{array}{c}\text { Placebo group: NO } \\
\text { Randomization: } \\
\text { YES } \\
\text { Double-blind: YES } \\
\text { Appropriate } \\
\text { statistical analysis: } \\
\text { NO }\end{array}$ & \\
\hline $\begin{array}{c}\text { Prospective, } \\
\text { randomized, } \\
\text { double-blind, placebo } \\
\text { controlled study } \\
\text { Healthy men, } \\
\text { spontaneously } \\
\text { complaining of ED, } \\
\geq 40 \text { years of age }\end{array}$ & $\begin{array}{l}\text { IIEF and serum } \\
\text { testosterone were } \\
\text { obtained before } \\
\text { randomization and } \\
\text { after } 30 \text { days of } \\
\text { study }\end{array}$ & $\begin{array}{l}\text { No effects as compared } \\
\text { with the placebo }\end{array}$ & $\begin{array}{c}\text { Part of the plant: } \\
\text { NO }\end{array}$ & $\begin{array}{l}\text { Santos et al. } \\
\qquad(2014)\end{array}$ \\
\hline TT extract & & & $\begin{array}{c}\text { Phytochemical } \\
\text { analysis or } \\
\text { standardization: } \\
\text { NO } \\
\text { Placebo group: } \\
\text { YES } \\
\text { Randomization: } \\
\text { YES } \\
\text { Double-blind: YES } \\
\text { Appropriate } \\
\text { statistical analysis: } \\
\text { YES }\end{array}$ & \\
\hline $\begin{array}{c}\text { Randomized, } \\
\text { double-blind, placebo } \\
\text { controlled clinical trial } \\
\text { study }\end{array}$ & & & $\begin{array}{c}\text { Part of the plant: } \\
\text { YES }\end{array}$ & \\
\hline $\begin{array}{l}\text { Women with } \\
\text { hypoactive sexual } \\
\text { desire disorder }\end{array}$ & FSFI score & FSFI $\uparrow^{*}$ & Origin: YES & $\begin{array}{l}\text { Akhtari et al. } \\
\text { (2014)[83] }\end{array}$ \\
\hline TT leaves extract & & & $\begin{array}{c}\text { Phytochemical } \\
\text { analysis or } \\
\text { standardization: } \\
\text { NCS } \\
\text { Placebo group: } \\
\text { YES } \\
\text { Randomization: } \\
\text { YES } \\
\text { Double-blind: YES } \\
\text { Appropriate } \\
\text { statistical analysis: } \\
\text { YES }\end{array}$ & \\
\hline $\begin{array}{c}\text { Prospective, } \\
\text { randomized, } \\
\text { double-blind, placebo } \\
\text { controlled clinical trial }\end{array}$ & IIEF score & IIEF score $\uparrow^{*}$ & $\begin{array}{c}\text { Part of the plant: } \\
\text { YES }\end{array}$ & $\begin{array}{l}\text { Kamenov et al. } \\
\text { (2017) }\end{array}$ \\
\hline $\begin{array}{l}\text { Male with mild to } \\
\text { moderate ED }\end{array}$ & GEQ responses & GEQ responses $\uparrow^{*}$ & Origin: YES & [71] \\
\hline $\begin{array}{l}\text { TT product: } \\
\text { Tribestan®, }\end{array}$ & & & $\begin{array}{l}\text { Phytochemical } \\
\text { analysis or } \\
\text { standardization: } \\
\text { YES }\end{array}$ & \\
\hline
\end{tabular}


Table 3. Cont.

\begin{tabular}{|c|c|c|c|c|}
\hline $\begin{array}{l}\text { Herbal Drug and } \\
\text { Subjects }\end{array}$ & Assay/Parameters & $\begin{array}{c}\text { Outcome of Treated } \\
\text { Group }\end{array}$ & $\begin{array}{l}\text { Study Design } \\
\text { Evaluation }\end{array}$ & Reference \\
\hline $\begin{array}{l}\text { 12-Week treatment } \\
\text { period }\end{array}$ & & & $\begin{array}{c}\text { Placebo group: } \\
\text { YES } \\
\text { Randomization: } \\
\text { YES } \\
\text { Double-blind: YES } \\
\text { Appropriate } \\
\text { statistical analysis: } \\
\text { YES }\end{array}$ & \\
\hline $\begin{array}{l}\text { Single-blind, placebo } \\
\text { controlled, parallel } \\
\text { study }\end{array}$ & MRS & $\begin{array}{l}\text { Severity of menopausal } \\
\text { transition sympt. } \downarrow^{*}\end{array}$ & $\begin{array}{c}\text { Part of the plant: } \\
\text { YES }\end{array}$ & $\begin{array}{c}\text { Fatima and } \\
\text { Sultana (2017) }\end{array}$ \\
\hline $\begin{array}{l}\text { Perimenopausal } \\
\text { women }\end{array}$ & $\begin{array}{l}\text { Severity of } \\
\text { menopausal } \\
\text { transition } \\
\text { symptoms }\end{array}$ & MRS $\downarrow^{*}$ & Origin: YES & [82] \\
\hline TT fruit extract & & & $\begin{array}{l}\text { Phytochemical } \\
\text { analysis or } \\
\text { standardization: } \\
\text { NCS } \\
\text { Placebo group: } \\
\text { YES } \\
\text { Randomization: } \\
\text { YES } \\
\text { Double-blind: NO } \\
\text { (single-blind) } \\
\text { Appropriate } \\
\text { statistical analysis: } \\
\text { YES }\end{array}$ & \\
\hline $\begin{array}{c}\text { Prospective, } \\
\text { randomized, } \\
\text { double-blind, placebo } \\
\text { controlled trial, } \\
\text { Premenopausal }\end{array}$ & FSFI score & FSFI $\uparrow^{*}$ & $\begin{array}{c}\text { Part of the plant: } \\
\text { NCS }\end{array}$ & $\begin{array}{l}\text { Vale et al. } \\
\quad(2018)\end{array}$ \\
\hline $\begin{array}{l}\text { women with } \\
\text { diminished libido }\end{array}$ & QS-F score & QS-F $\uparrow^{*}$ & Origin: YES & [81] \\
\hline TT extract & Serum testosterone & Serum testosterone $\uparrow^{*}$ & $\begin{array}{c}\text { Phytochemical } \\
\text { analysis or } \\
\text { standardization: } \\
\text { NCS } \\
\text { Placebo group: } \\
\text { YES } \\
\text { Randomization: } \\
\text { YES } \\
\text { Double-blind: YES } \\
\text { Appropriate } \\
\text { statistical analysis: } \\
\text { YES }\end{array}$ & \\
\hline
\end{tabular}

MF, mount frequency; IF, intromission frequency; ML, mount latency; IL, intromission latency; EL, ejaculation latency; PEI, post-ejaculatory interval; ICP, intracavernous pressure; NCS, not clearly specified; cAMP, adenosine $3^{\prime}, 5^{\prime}$-cyclic monophosphate; cGMP, guanosine $3^{\prime}, 5^{\prime}$-cyclic monophosphate; FSH, follicle-stimulating hormone; LPO, lipid peroxidation; SOD, superoxide dismutase; CAT, catalase; GPx, glutathione peroxidase; GST, glutathione; $\mathrm{S}$, transferase; AR, androgen receptor; IGF-1R, insulin growth factor 1 receptor; UHPLC-Q-TOF/MS, ultra-high performance liquid chromatography-quadrupole-time of flight mass spectrometry; GR, glutathione reductase; GSH, glutathione; $17 \beta$-HSD, $17 \beta$-hydroxysteroid dehydrogenase; $\mathrm{LH}$, luteinizing hormone; MAP, mean arterial pressure; eNOS, endothelial nitric oxide synthase; urinary T/E ratio, urinary testosterone/epitestosterone (T/E) ratio; CK, creatine kinase; ED, erectile dysfunction; IIEF, International Index of Erectile Function; SQoLM, Sexual quality of life questionnaire male; FSFI, Female Sexual Function Index; GEQ, Global Efficacy Question; MRS, menopause rating scale; QS-F, Sexual Quotient Female Version; *, statistically significant difference as compared with the control/placebo; \#, statistically significant difference as compared with the positive control group. 


\subsection{Antibacterial Activity}

There are several in vitro studies that have revealed the antibacterial potency of TT total or fractionated extracts on Gram-negative and Gram-positive bacterial strains. Among the Gram-positive bacteria, facultative anaerobe strains such as Staphylococcus aureus, Streptoccocus mutans, Streptococcus sanguinis, Actinomyces viscosus, Enteroccocus faecalis, and Bacillus subtilis were susceptible and among the Gram-negative bacteria Escherichia coli, Salmonella typhi, Proteus mirabilis, and Klebsiella pneumoniae were susceptible [87-92]. It is still unclear which components are responsible for the antibacterial activity, but alkaloids contribute to the general antibacterial effect of the total extracts [88]. The antibacterial effects of saponins are well documented and the mechanism of action is based on the destruction of the cell membrane, leading to cell death (bactericidal effect), probably due to their amphiphilic nature and their surfactant properties. In addition, it was noticed that saponins could modulate ion channels, influencing the membrane potential [93,94]. Kianbakht and Jahaniani [92] found that the antibacterial activity of extract from TT roots was lower than the activity of the extracts obtained from the fruits and stems plus leaves. Although the authors did not provide a phytochemical profile of the extracts, we have shown in Table 2 that furostanol and spirostanol saponins were mainly identified and quantified in the aerial parts of TT rather than in the roots. However, alkaloids were identified in all organs. These results suggest that the antibacterial activity of TT is correlated mostly with the saponin content. Flavonoid fractions from TT leaves and fruits have also been proven to have antibacterial activity against E. coli, Salmonella, Staphylococcus aureus, and Streptococcus [39,40].

A recently published paper demonstrated the quorum quenching activity of TT (origin India) root extracts on Chromobacterium violaceum, Serratia marcescens, and Pseudomonas aeruginosa strains. The main compound was found to be $\beta-1,5$-O-dibenzoyl ribofuranose [51].

\subsection{Antihyperglycemic Effect}

\subsubsection{In Vitro Determinations}

Studies conducted with extracts from TT have been shown to inhibit the activity of alpha-glucosidase and alpha-amylase in vitro. Alpha-glucosidase and alpha-amylase are enzymes involved in the hydrolysis of carbohydrates. Alpha-amylase breaks down the oligosaccharides into disaccharides and alpha-glucosidase breaks down the disaccharides into absorbable monosaccharides. Inhibition of the activity of these enzymes has been proven to reduce postprandial hyperglycemia in diabetic patients. The TT extracts exhibited a relatively higher inhibition capacity on alpha-amylase than on that of alpha-glucosidase [95]. The activity of the total extract was higher than the activity of isolated saponin, meaning that there are other constituents in the TT extract that act synergistically. As reported by Song et al., cinnamic acid amides also have the capacity to inhibit the activity of alpha-glucosidase [36]. Ponnusamy et al. [96] concluded that TT had a lower capacity of inhibition of the activity of alpha-glucosidase as compared with other extracts.

\subsubsection{Preclinical Studies}

In vivo animal studies are in concordance with the in vitro studies, as it was shown that the saponins from TT administered to rats were able to delay the postprandial hyperglycemia by inhibiting alpha-glucosidase [97]. Studies on diabetic rats and glucose-loaded rabbits have shown that TT extracts are also capable of reducing fasting blood glucose levels, which suggests that the active compounds have multiple mechanisms of action [98-100]. Although the majority of the preclinical research for TT extracts was conducted on diabetic rats in order to evaluate the effect on different complications caused by diabetes, mostly related to sexual disorders, all studies reported the antihyperglycemic effect of TT extracts $[67,85,86]$. Diosgenin was shown to promote insulin secretion and influence beta cell regeneration in STZ-induced diabetes in rats through PPAR $\gamma$ activation in adipose tissue and oxidative stress modulation [101,102]. Stimulation of PPAR $\gamma$ nuclear receptors as a likely mechanism of the antihyperglycemic effect of diosgenin could explain the insulin-sensitizing action by altering the 
free fatty acid/glucose ratio by facilitating their intracellular uptake into muscle and adipose tissue. Intracellular uptake of both glucose and free fatty acids could be the consequence of stimulating the expression of GLUT-4 (glucose transporter 4) and CD36 (cluster of differentiation 36 or fatty acid translocase) as a result of PPAR $\gamma$ receptor activation (Figure 4).

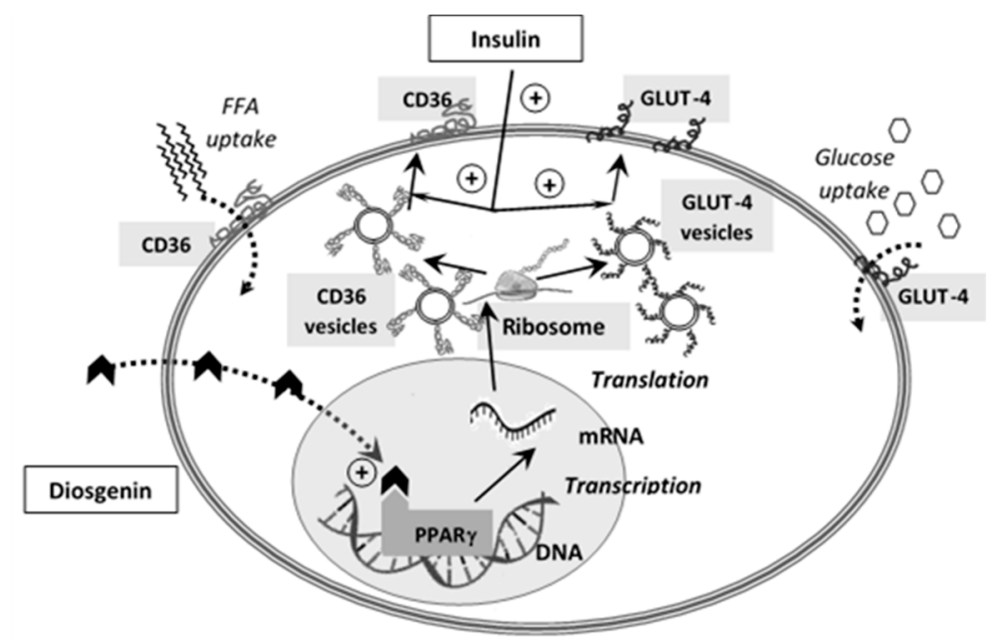

Figure 4. The presumed mechanism of diosgenin stimulation of PPAR $\gamma$ receptors. PPAR $\gamma$, peroxisome proliferator-activated receptor gamma; DNA, deoxyribonucleic acid; mRNA, messenger ribonucleic acid; FFA, free fatty acids; GLUT-4, glucose transporter 4; and CD36, cluster of differentiation 36 (fatty acid translocase).

Alkaloids could act synergistically with the steroidal saponins, as it was shown that imidazolidine derivatives stimulate insulin secretion by activation of imidazoline receptor type 3 binding sites in the pancreatic beta cells [103].

\subsubsection{Clinical Studies}

Samani et al. [104] conducted a double-blind, randomized placebo controlled clinical trial that included ninety-eight women. The study concluded that TT extract significantly lowered the blood glucose level of diabetic patients as compared with the placebo group. Another study conducted by Ramteke et al. [105] included 100 patients with diabetes mellitus and microalbuminuria. The results showed that the group treated with an ayurvedic preparation that contained TT had significantly lower blood glucose after the treatment as compared with the initial blood glucose level and the microalbuminuria was also reduced.

Recent research suggests that there is a correlation between testosterone levels and type 2 diabetes and that low testosterone levels in men predict a high risk of type 2 diabetes [106]. The direct and indirect androgenic action of TT extracts could also contribute to the improvement in the glycemic profile of diabetic patients, as it is known that androgens increase carbohydrate tolerance and promote glycogenesis [107].

Table 4 summarizes the most relevant results obtained in pharmacological studies related to the antihyperglycemic effect of TT. 
Table 4. In vitro and in vivo pharmacological studies and the study design evaluation.

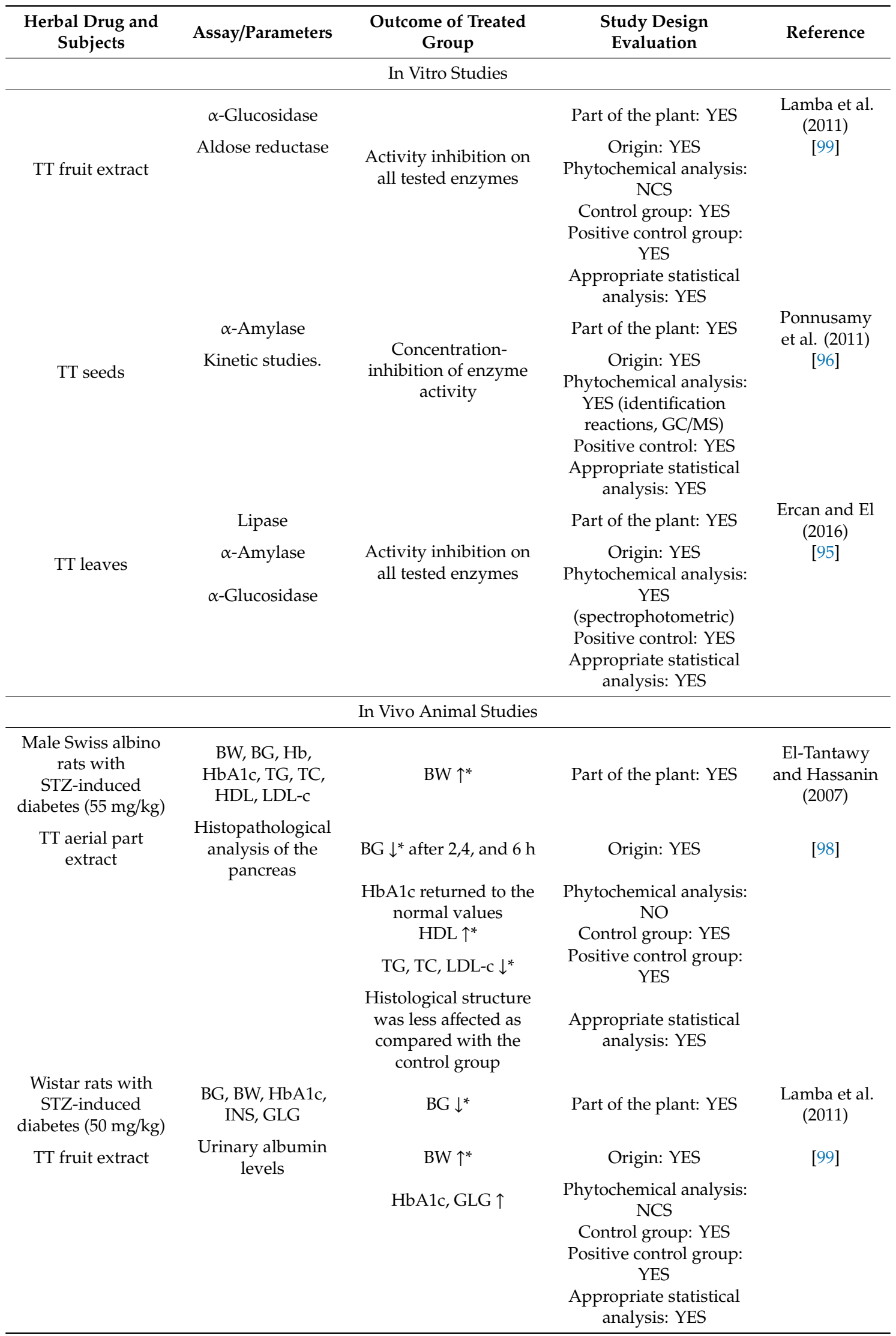


Table 4. Cont.

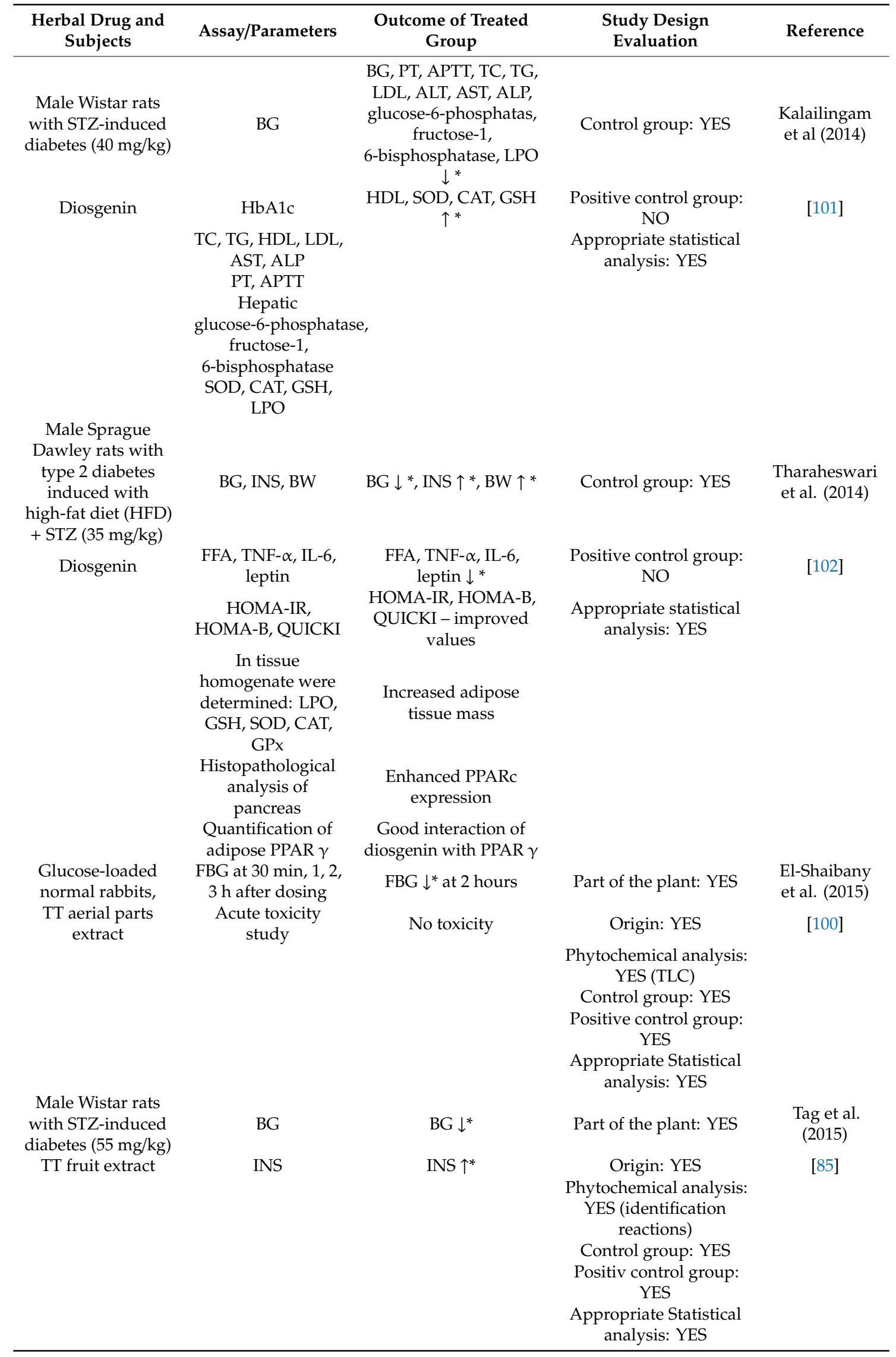


Table 4. Cont.

\begin{tabular}{|c|c|c|c|c|}
\hline $\begin{array}{l}\text { Herbal Drug and } \\
\text { Subjects }\end{array}$ & Assay/Parameters & $\begin{array}{c}\text { Outcome of Treated } \\
\text { Group }\end{array}$ & $\begin{array}{l}\text { Study Design } \\
\text { Evaluation }\end{array}$ & Reference \\
\hline $\begin{array}{l}\text { Sprague Dawley } \\
\text { rats with type } 2 \\
\text { diabetes induced } \\
\text { with high-fat and } \\
\text { high-sugar feeding } \\
\text { and STZ ( } 30 \mathrm{mg} / \mathrm{kg} \text { ) }\end{array}$ & BG & BG $\downarrow$ & Part of the plant: NO & $\begin{array}{l}\text { Zhang et al. } \\
\text { (2019) }\end{array}$ \\
\hline \multirow[t]{2}{*}{$\begin{array}{l}\text { Gross saponins of } \\
\text { TT }\end{array}$} & \multirow[t]{2}{*}{ BW } & \multirow[t]{2}{*}{$\begin{array}{c}\text { No significant } \\
\text { differences in BW }\end{array}$} & Origin: YES & [86] \\
\hline & & & $\begin{array}{c}\text { Phytochemical analysis: } \\
\text { NCS } \\
\text { Control group: YES } \\
\text { Positive control group: } \\
\text { YES } \\
\text { Appropriate statistical } \\
\text { analysis: YES }\end{array}$ & \\
\hline \multicolumn{5}{|c|}{ Clinical Studies } \\
\hline $\begin{array}{c}100 \text { Patients } \\
\text { suffering from DM } \\
\text { with } \\
\text { microalbuminuria } \\
\text { Ayurvedic }\end{array}$ & BG & $\mathrm{BG} \downarrow *$ & Part of the plant: NCS & $\begin{array}{l}\text { Ramteke et al. } \\
\text { (2012) }\end{array}$ \\
\hline \multirow[t]{2}{*}{$\begin{array}{c}\text { preparation with } \\
\text { TT }\end{array}$} & $\mathrm{BP}$ & $\mathrm{BP} \downarrow *$ & Origin: NCS & [105] \\
\hline & Urine albumin & Urine albumin $\downarrow^{*}$ & $\begin{array}{l}\text { Phtochemical analysis or } \\
\text { standardization: NO } \\
\text { Placebo group: NO } \\
\text { Randomization: YES } \\
\text { Double-blind: NCS } \\
\text { Appropriate statistical } \\
\text { analysis: YES }\end{array}$ & \\
\hline $\begin{array}{l}\text { Double-blind } \\
\text { randomized } \\
\text { placebo controlled } \\
\text { clinical trial }\end{array}$ & $\begin{array}{l}\text { FBG, BG 2-hour } \\
\text { postprandial } \\
\text { HbA1c }\end{array}$ & $\mathrm{BG} \downarrow^{*}$ & Part of the plant: NCS & \\
\hline $\begin{array}{l}\text { Ninety-eight } \\
\text { women with } \\
\text { diabetes mellitus } \\
\text { type } 2\end{array}$ & TG, TC, LDL, HDL & $\mathrm{TC}, \mathrm{LDL} \downarrow^{*}$ & Origin: YES & $\begin{array}{l}\text { Samani et al. } \\
(2016)[104]\end{array}$ \\
\hline \multirow[t]{2}{*}{ TT extract } & & $\begin{array}{l}\text { HbA1c, TG, HDL - no } \\
\text { significant differences } \\
\text { as compared with the } \\
\text { placebo }\end{array}$ & $\begin{array}{l}\text { Phtochemical analysis or } \\
\text { standardization: YES }\end{array}$ & \\
\hline & & & $\begin{array}{l}\text { Placebo group: YES } \\
\text { Randomization: YES } \\
\text { Double-blind: YES } \\
\text { Appropriate statistical } \\
\text { analysis: YES }\end{array}$ & \\
\hline
\end{tabular}

NCS, not clearly specified; GC/MS, gas chromatography-mass spectrometry; TLC, thin layer chromatography; STZ, streptozotocin; BW, bodyweight; BG, blood glucose; Hb, hemoglobin; HbA1c, glycosylated hemoglobin; TG, serum triglycerides; TC, total cholesterol; HDL, high density lipoprotein; LDL-c, low density lipoprotein cholesterol; INS, insulin; GLG, glycogen; FBG, fasting blood glucose; AST, aspartate aminotransferase; ALP, alkaline phosphatase; PT, prothrombin time; APTT, activated partial thromboplastin time; SOD, superoxide dismutase; CAT, catalase; GSH, glutathione; LPO, lipid peroxidase; FFA, serum free fatty acids; TNF- $\alpha$, tumor necrosis factor- $\alpha$; IL- 6 , interleukin- 6 ; HOMA-IR, homeostasis model assessment of insulin resistance; HOMA-B, homeostasis model assessment of $\beta$-cell function; QUICKI, quantitative insulin sensitivity check index, PPAR $\gamma$, peroxisome proliferator-activated receptor gamma; GPx, glutathione peroxidase; BP, blood pressure; *, significant difference as compared with the control group and the placebo group. 


\subsection{Anti-Inflammatory Properties}

\subsubsection{In Vitro Studies}

Several studies have demonstrated that extracts of TT have anti-inflammatory activities. The primary mechanisms involved are thought to be downregulation of inflammatory pathway protein $\mathrm{NFK}_{K} \mathrm{~B}$ [46]. The extract used was standardized in tribulusterine (aqueous extract with $0.54 \mathrm{mg} \%$ tribulusterine, origin India, part of the plant used not specified). Because the protein NFkB is also a mediator of cell cycle and cell survival, it has been shown that TT extracts can induce apoptosis in human liver cancer cells by inhibiting the NFKB signaling pathway (aqueous extract from fruits, origin Korea) [108]. Research has also shown that the extracts have an anti-inflammatory effect even in the topical application by affecting modulation of the calcium channels Orai-1 and TRPV3, as well as by inhibiting mast cell activation (ethanolic extract from fruits, origin Korea) [43]. The only compound identified in TT extract was rutin. Lee et al. [48] assessed the anti-inflammatory effects of tribulusamide D isolated from the fruits of TT in an in vitro study (origin Korea). They suggested that the effect occurred through the downregulation of enzymes responsible for the production of cytokines and inflammatory mediators. Hong et al. [109], demonstrated that TT fruits extract (origin Korea) inhibited the COX-2 activity. Other in vitro studies have shown that TT extracts have anti-inflammatory effects [39,110].

\subsubsection{In Vivo Studies}

Animal experiments have confirmed the anti-inflammatory effects demonstrated in vitro. Mohammed et al. [111] showed that the methanolic extract from the aerial parts of TT (origin Sudan) and the chloroformic fraction had significant anti-inflammatory effects in rat paw edema induced with carrageenan as compared with the untreated group. The anti-inflammatory effect of a flavonoid fraction from TT leaves was also evaluated in an ear swelling model induced by xylene in mice. The study demonstrated that the flavonoid fraction reduced the swelling degree in a dose-dependent manner [39]. Qiu et al. [112] tested terrestrosin D on bleomycin-induced inflammation in mice. They concluded that TT administration suppressed the inflammatory and fibrotic changes induced by bleomycin in the lungs.

\subsection{Action on the Central Nervous System}

The $\beta$-Carboline indole alkaloids are known to be monoamine oxidase inhibitors (MAOIs), primarily MAO-A, as they prevent biogenic amine from binding to the active site of the MAO molecule and undergoing deamination. Consequently, their presence in TT is thought to have been responsible for the unusual locomotory disturbance in sheep that grazed in areas with TT [45,113]. If this action is maintained in humans, special precautions should be taken in patients under treatment with monoamine oxidase inhibitors.

In several studies, the neuroprotective effect has been demonstrated and several mechanisms of action have been proposed. Chaudary et al. [114] demonstrated the neuroprotective effect of TT extracts (fruits part of the plant, origin Pakistan) in aluminum chloride-induced Alzheimer's disease in rats. Biochemical and behavioral parameters improvement were connected with the antioxidant activity of the extract and also with the chelating properties of flavonoids. Song et al. [115] evaluated the anticonvulsant effect of protodioscin on a pilocarpine-induced convulsion model in mice and suggested that the effect was modulated through the GABAergic system.

Part of the previously mentioned effects of TT extracts is mediated through the central nervous system, and therefore are not included in the present section. These include the modulation of pituitary gonadotropin secretion. The toxic effects observed in sheep also involve the modulation of the GABAergic and dopaminergic system and are further presented. 


\subsection{Toxicological Studies}

\subsubsection{In Vitro Studies}

Evaluation of toxicological effects in vitro has demonstrated that TT extracts (part of the plant not specified, origin Turkey) have estrogenic and genotoxic effects [116].

\subsubsection{Preclinical Experimental Studies (Animal Models)}

Hepatogenous photosensitivity appeared after 11 days in sheep fed with a mixture of TT and alfalfa (Medicago sativa). The symptoms included depression, jaundice, weight loss, conjunctivitis, and also the reddening of the muzzle, nose, ears, and eyelids [117]. The study conducted by Gandhi et al. [118], on diabetic rats, was inconclusive with respect to the nephrotoxic effects of TT extract (50 mg hydroalcoholic extract $/ \mathrm{kg}$ with $45 \%$ saponins). Although an improvement in kidney function was expected after the treatment, no improvement was noticed [118]. Bourke [119] reported that a specific, irreversible, asymmetrical locomotor disorder appeared in sheep that ingested large quantities of TT. Administration of levodopa to the affected and nonaffected sheep, followed by the removal of the striatum and the quantification of dopamine and 3,4-dihydroxyphenylacetic acid, led the author to the conclusion that chronic intake of large quantities of TT caused a malfunction of the striatal presynaptic receptor, affecting the nigrostriatal pathway. The same author, along with other scientists, continued the research in this field and indicated harmane and norharmane as two possible neurotoxins [45].

Acute and subacute toxicity tests were performed by Hemalatha and Hari [120] with butanolic extract from TT fruits (origin India). No signs of significant toxicity were noticed. Also, El-Shaibany et al. [100] concluded that there were no toxic symptoms, deaths or behavioral changes in an acute toxicity study in rabbits treated with TT aerial parts extract (origin Yemen).

\subsubsection{Case Reports}

Talasaz et al. [121] reported a severe case of nephrotoxicity in a 28-year-old man, after the consumption of TT water. There is also a published case presentation in which a 36-year-old man, who consumed a herbal supplement based on a TT extract, was diagnosed with a 72-hour priapism [122]. It was presumed that the priapism was caused by TT supplement, and no further analysis of the supplement was performed; therefore, a pertinent conclusion cannot be drawn regarding this side effect, i.e., if it was caused by the extract found in the supplement or by an unknown compound with which the supplement was impurified. Another reported case of toxicity caused by consumption of TT supplements was that of a 30-year-old male, diagnosed with hyperbilirubinemia, cholestasis, and bilirubin-induced toxic acute tubular necrosis [123]. As in the previous case, the analysis of the supplement was not performed.

The toxicity of TT extracts has not been fully evaluated, and the toxic compounds have not been properly identified.

With respect to the reported cases of toxicity, no clinical trial in which TT-based products were administered, have reported these side effects. Particular attention should be given to the herbal supplements, and an elaborate analysis should be performed in order to identify the toxic compounds. There is a constant risk of adulteration of food supplements, primarily when these are used for their anabolic effects. There is also the possibility of trace metal accumulation in herbal drugs. A single research article was found that analyzed the content of some essential and trace elements in TT organs [124]. Although the results did not indicate toxic concentrations in the samples, a routine analysis of these elements should be performed for the food supplements. Antinutritional factors (hydrocyanic acid, phytate, nitrate, and oxalate) in TT leaves were also identified [125]. Seven compounds (listed in Table 5) from TT have a toxicological profile in the U.S. National Library of Medicine [126]. Harmine was the only compound found to have a complete toxicological profile. Effects of toxic doses are tremor, sleepiness, nausea or vomiting (man), excitement, mydriasis, dyspnea and ataxia (rabbit), and excitements (mouse). 
Table 5. Toxicological information of some compounds from the U.S. National Library of Medicine [126].

\begin{tabular}{cc}
\hline Compound & Toxicological Information \\
\hline \multirow{2}{*}{ Diosgenin } & Oral LD50 (rat) $>8 \mathrm{~g} / \mathrm{kg}$ \\
& Intraperitoneal LD50 (rat) $4872 \mathrm{mg} / \mathrm{kg}$ \\
Oral LD50 (mouse) $>8 \mathrm{~g} / \mathrm{kg}$ \\
Intraperitoneal LD50 (mouse) $3564 \mathrm{mg} / \mathrm{kg}$ \\
\hline Dioscin & Subcutaneous LD50 (mouse) $>300 \mathrm{mg} / \mathrm{kg}$ \\
& Oral TDLo (rat) $1050 \mathrm{mg} / \mathrm{kg} / 1 \mathrm{~W}$ (intermittent) \\
Oral TDLo (mouse):400 mg/kg/10D (intermittent) \\
\hline Tigogenin & Intraperitoneal LDLo (rat):10 mg/kg \\
\hline & Intramuscular TDLo (man):3 mg/kg \\
& Intravenous LDLo (cat) $10 \mathrm{mg} / \mathrm{kg}$ \\
Harmine & Subcutaneous LDLo (frog) $300 \mathrm{mg} / \mathrm{kg}$ \\
& Subcutaneous LD50 (mouse) $243 \mathrm{mg} / \mathrm{kg}$ \\
& Intravenous LDLo (mouse) $50 \mathrm{mg} / \mathrm{kg}$ \\
& Subcutaneous LD50 (rat) $200 \mathrm{mg} / \mathrm{kg}$ \\
\hline Harmane & Intraperitoneal LD50 (mouse) $50 \mathrm{mg} / \mathrm{kg}$ \\
& Interperitoneal TDLo (rat) $1 \mathrm{mg} / \mathrm{kg}$ \\
& Intraperitoneal LD50 (rabbit) $200 \mathrm{mg} / \mathrm{kg}$ \\
\hline LD50, median lethal dose; TDLo, lowest published toxic dose; LDLo, lowest lethal dose.
\end{tabular}

Considering all of the above information, a complete analysis of the supplements should be performed when a toxicity case is reported.

\section{Conclusions}

Different phytochemical profiles of the herbal drugs from TT, highlighted both in the concentration of the main active compounds and in the absence of some active compounds, explain the major differences in the therapeutic effects reported over the years in the literature. The main pharmacological research on TT has been focused on sexual disorders, but other important effects have been demonstrated in vitro and in vivo studies, i.e., anti-hyperglycaemic, anti-inflammatory, antioxidant, and antibacterial. Toxicological studies, although limited, have highlighted the risk of nephrotoxicity following the administration of TT supplements. However, additional studies are needed to determine some of the still unknown molecular mechanisms of action of the therapeutic active compounds found in Tribulus extracts. Although TT has been extensively researched, further studies are needed in order to clarify important aspects such as a more accurate correlation between the phytochemical and pharmacological profiles, pharmacokinetic studies of the most important compounds, as well as the evaluation of possible pharmacokinetic and pharmacodynamic interactions with other compounds. Researchers should provide full information on the plant origin and the tested organ. Methods for standardization are necessary in order to achieve reproducible results. To date, it seems that the chemical compounds found in TT are capable of activating multiple pathways, hence, the various effects.

Author Contributions: Writing-original draft preparation, R.S.., A.N., and E.A.; writing-review and editing, R.S.., A.T.-V., and C.-E.V.; visualization, R.Ș., A.T.-V., and C.-E.V.; funding acquisition, R.S. All authors have read and agreed to the published version of the manuscript

Funding: This research was supported by a project funded by the Internal Research Grants of the University of Medicine and Pharmacy of Targu Mureş, Romania (grant contract for execution of research projects no. 15609/10/29.12.2017). 
Acknowledgments: This research was supported by a project funded by the Internal Research Grants of the University of Medicine and Pharmacy of Targu Mureş, Romania (grant contract for execution of research projects no. 15609/10/29.12.2017). The authors would like to thank Mr. Adrian Naznean for the English language revision of the manuscript.

Conflicts of Interest: The authors declare no conflict of interest. The funders had no role in the design of the study; in the collection, analyses, or interpretation of data; in the writing of the manuscript, or in the decision to publish the results.

\section{References}

1. Pokrywka, A.; Obmiński, Z.; Malczewska-Lenczowska, J.; Fijałek, Z.; Turek-Lepa, E.; Grucza, R. Insights into Supplements with Tribulus Terrestris used by Athletes. J. Hum. Kinet. 2014, 41, 99-105. [CrossRef] [PubMed]

2. Neychev, V.; Mitev, V. Pro-sexual and androgen enhancing effects of Tribulus terrestris L.: Fact or Fiction. J. Ethnopharmacol. 2016, 179, 345-355. [CrossRef]

3. Dinchev, D.; Janda, B.; Evstatieva, L.; Oleszek, W.; Aslani, M.R.; Kostova, I. Distribution of steroidal saponins in Tribulus terrestris from different geographical regions. Phytochemistry 2008, 69, 176-186. [CrossRef] [PubMed]

4. Lazarova, I.; Ivanova, A.; Mechkarova, P.; Peev, D.; Valyovska, N. Intraspecific variability of biologically active compounds of different populations of Tribulus terrestris L. (Zygophyllaceae) in South Bulgaria. Biotechnol. Biotechnol. Equip. 2011, 25, 2352-2356. [CrossRef]

5. GamalEl Din, S.F. Role of Tribulus terrestris in Male Infertility: Is It Real or Fiction? J. Diet. Suppl. 2018, 15, 1010-1013. [CrossRef]

6. Kostova, I.; Dinchev, D. Saponins in Tribulus terrestris-Chemistry and bioactivity. Phytochem. Rev. 2005, 4, 111-137. [CrossRef]

7. Hashim, S.; Bakht, T.; Bahadar Marwat, K.; Jan, A. Medicinal properties, phytochemistry and pharmacology of Tribulus terrestris L. (Zygophyllaceae). Pakistan J. Bot. 2014, 46, 399-404.

8. Chhatre, S.; Nesari, T.; Kanchan, D.; Somani, G.; Sathaye, S. Phytopharmacological overview of Tribulus terrestris. Pharmacogn. Rev. 2014, 8, 45-51. [CrossRef]

9. Yanala, S.R.; Sathyanarayana, D.; Kannan, K. A recent phytochemical review-Fruits of Tribulus terrestris linn. J. Pharm. Sci. Res. 2016, 8, 132-140.

10. Sivapalan, S.R. Biological and pharmacological studies of Tribulus terrestris Linn- A review. Int. J. Multidiscip. Res. Dev. 2016, 3, 257-265.

11. Zhu, W.; Du, Y.; Meng, H.; Dong, Y.; Li, L. A review of traditional pharmacological uses, phytochemistry, and pharmacological activities of Tribulus terrestris. Chem. Cent. J. 2017, 11, 1-16. [CrossRef]

12. Azam, F.; Munier, S.; Abbas, G. A review on advancements in ethnomedicine and phytochemistry of Tribulus terrestris - a plant with multiple health benefits. Int. J. Biosci. 2019, 14, 21-37.

13. Sanagoo, S.; Sadeghzadeh Oskouei, B.; Gassab Abdollahi, N.; Salehi-Pourmehr, H.; Hazhir, N.; Farshbaf-Khalili, A. Effect of Tribulus terrestris L. on sperm parameters in men with idiopathic infertility: A systematic review. Complement. Ther. Med. 2019, 42, 95-103. [CrossRef]

14. Semerdjieva, I.B.; Zheljazkov, V.D. Chemical Constituents, Biological Properties, and Uses of Tribulus terrestris: A Review. Nat. Prod. Commun. 2019, 14, 1-26. [CrossRef]

15. Meena, P.; Anand, A.; Vishal, K. A comprehensive overview of Gokshura (Tribulus terrestris Linn.). J. Ayurveda Integr. Med. Sci. 2019, 4, 205-211.

16. De Combarieu, E.; Fuzzati, N.; Lovati, M.; Mercalli, E. Furostanol saponins from Tribulus terrestris. Fitoterapia 2003, 74, 583-591. [CrossRef]

17. Ganzera, M.; Bedir, E.; Khan, I.A. Determination of steroidal saponins in Tribulus terrestris by reversed-phase high-performance liquid chromatography and evaporative light scattering detection. J. Pharm. Sci. 2001, 90, 1752-1758. [CrossRef]

18. Sarvin, B.; Stekolshchikova, E.; Rodin, I.; Stavrianidi, A.; Shpigun, O. Optimization and comparison of different techniques for complete extraction of saponins from T. terrestris. J. Appl. Res. Med. Aromat. Plants 2018, 8, 75-82. [CrossRef]

19. Kostova, I.; Dinchev, D.; Rentsch, G.H.; Dimitrov, V.; Ivanova, A. Two new sulfated furostanol saponins from Tribulus terrestris. Zeitschrift fur Naturforsch. - Sect. C J. Biosci. 2002, 57, 33-38. [CrossRef] [PubMed] 
20. Huang, J.W.; Tan, C.H.; Jiang, S.H.; Zhu, D.Y. Terrestrinins A and B, two new steroid saponins from Tribulus terrestris. J. Asian Nat. Prod. Res. 2003, 5, 285-290. [CrossRef] [PubMed]

21. Skhirtladze, A.; Nebieridze, V.; Benidze, M.; Kemertelidze, E.; Ganzera, M. Furostanol glycosides from the roots of Tribulus terrestris L. Bull. Georg. Natl. Acad. Sci. 2017, 11, 122-126.

22. Zhang, C.; Wang, S.; Guo, F.; Ma, T.; Zhang, L.; Sun, L.; Wang, Y.; Zhang, X. Analysis of variations in the contents of steroidal saponins in Fructus Tribuli during stir-frying treatment. Biomed. Chromatogr. 2020, 34, e4794. [CrossRef] [PubMed]

23. Zheng, W.; Wang, F.; Zhao, Y.; Sun, X.; Kang, L.; Fan, Z.; Qiao, L.; Yan, R.; Liu, S.; Ma, B. Rapid Characterization of Constituents in Tribulus terrestris from Different Habitats by UHPLC/Q-TOF MS. J. Am. Soc. Mass Spectrom. 2017, 28, 2302-2318. [CrossRef] [PubMed]

24. Wang, Z.F.; Wang, B.B.; Zhao, Y.; Wang, F.X.; Sun, Y.; Guo, R.J.; Song, X.B.; Xin, H.L.; Sun, X.G. Furostanol and Spirostanol Saponins from Tribulus terrestris. Molecules 2016, 21, 429. [CrossRef] [PubMed]

25. Xu, Y.J.; Xu, T.H.; Liu, Y.; Xie, S.X.; Si, Y.S.; Xu, D.M. Two new steroidal glucosides from Tribulus terrestris L. J. Asian Nat. Prod. Res. 2009, 11, 548-553. [CrossRef]

26. Bedir, E.; Khan, I.A. New steroidal glycosides from the fruits of Tribulus terrestris. J. Nat. Prod. 2000, 63, 1699-1701. [CrossRef]

27. Hammoda, H.M.; Ghazy, N.M.; Harraz, F.M.; Radwan, M.M.; ElSohly, M.A.; Abdallah, I.I. Chemical constituents from Tribulus terrestris and screening of their antioxidant activity. Phytochemistry 2013, 92, 153-159. [CrossRef]

28. Ivanova, A.; Serly, J.; Dinchev, D.; Ocsovszki, I.; Kostova, I.; Molnar, J. Screening of some saponins and phenolic components of Tribulus terrestris and Smilax excelsa as MDR modulators. In Vivo (Brooklyn). 2009, 23, 545-550.

29. Miles, C.O.; Wilkins, A.L.; Munday, S.C.; Flåøyen, A.; Holland, P.T.; Smith, B.L. Identification of Insoluble Salts of the $\beta$-d-Glucuronides of Episarsasapogenin and Epismilagenin in the Bile of Lambs with Alveld and Examination of Narthecium ossifragum, Tribulus terrestris, and Panicum miliaceum for Sapogenins. J. Agric. Food Chem. 1993, 41, 914-917. [CrossRef]

30. Burda, N.Y.; Zhuravel, I.O.; Dababneh, M.F.; Fedchenkova, Y.A. Analysis of diosgenin and phenol compounds in Tribulus terrestris L. Pharmacia 2019, 66, 41-44. [CrossRef]

31. Vaidya, V.; Kondalkar, P.; Shinde, M.; Gotmare, S. HPTLC fingerprinting for simultaneous quantification of harmine, kaempferol, diosgenin and oleic acid in the fruit extract of Tribulus terrestris and its formulation. Int. J. Pharm. Sci. Res. 2018, 9, 3066-3074.

32. Deepak, M.; Dipankar, G.; Prashanth, D.; Asha, M.K.; Amit, A.; Venkataraman, B.V. Tribulosin and $\beta$-sitosterol-D-glucoside, the anthelmintic principles of Tribulus terrestris. Phytomedicine 2002, 9, 753-756. [CrossRef] [PubMed]

33. Xu, Y.X.; Chen, H.S.; Liu, W.Y.; Gu, Z.B.; Liang, H.Q. Two sapogenins from Tribulus terrestris. Phytochemistry 1998, 49, 199-201. [CrossRef]

34. Wu, T.S.; Shi, L.S.; Kuo, S.C. Alkaloids and other constituents from Tribulus terrestris. Phytochemistry 1999, 50, 1411-1415. [CrossRef]

35. Ma, Y.; Guo, Z.; Wang, X. Tribulus terrestris extracts alleviate muscle damage and promote anaerobic performance of trained male boxers and its mechanisms: Roles of androgen, IGF-1, and IGF binding protein-3. J. Sport Heal. Sci. 2017, 6, 474-481. [CrossRef] [PubMed]

36. Song, Y.H.; Kim, D.W.; Curtis-Long, M.J.; Park, C.; Son, M.; Kim, J.Y.; Yuk, H.J.; Lee, K.W.; Park, K.H. Cinnamic acid amides from Tribulus terrestris displaying uncompetitive a-glucosidase inhibition. Eur. J. Med. Chem. 2016, 114, 201-208. [CrossRef]

37. Li, J.X.; Shi, Q.; Xiong, Q.B.; Prasain, J.K.; Tezuka, Y.; Hareyama, T.; Wang, Z.T.; Tanaka, K.; Namba, T.; Kadota, S. Tribulusamide A and B, new hepatoprotective lignanamides from the fruits of Tribulus terrestris: Indications of cytoprotective activity in murine hepatocyte culture. Planta Med. 1998, 64, 628-631. [CrossRef]

38. Bhutani, S.P.; Chibber, S.S.; Seshadri, T.R. Flavonoids of the fruits and leaves of Tribulus terrestris: Constitution of tribuloside. Phytochemistry 1969, 8, 299-303. [CrossRef]

39. Tian, C.; Chang, Y.; Zhang, Z.; Wang, H.; Xiao, S.; Cui, C.; Liu, M. Extraction technology, component analysis, antioxidant, antibacterial, analgesic and anti-inflammatory activities of flavonoids fraction from Tribulus terrestris L. leaves. Heliyon 2019, 5, e02234. [CrossRef] 
40. Tian, C.; Zhang, Z.; Wang, H.; Guo, Y.; Zhao, J.; Liu, M. Extraction technology, component analysis, and in vitro antioxidant and antibacterial activities of total flavonoids and fatty acids from Tribulus terrestris L. fruits. Biomed. Chromatogr. 2019, 33, 4. [CrossRef]

41. Louveaux, A.; Jay, M.; Hadi, O.T.M.E.; Roux, G. Variability in flavonoid compounds of four Tribulus species: Does it play a role in their identification by desert locust Schistocerca gregaria? J. Chem. Ecol. 1998, 24, 1465-1481. [CrossRef]

42. Kumar, A. Comparative and quantitative determination of quercetin and other flavonoids in North Indian populations of Tribulus terrestris Linn, by HPLC. Int. J. Pharma Bio Sci. 2012, 3, 69-79.

43. Kang, S.Y.; Jung, H.W.; Nam, J.H.; Kim, W.K.; Kang, J.S.; Kim, Y.H.; Cho, C.W.; Cho, C.W.; Park, Y.K.; Bae, H.S. Effects of the Fruit Extract of Tribulus terrestris on Skin Inflammation in Mice with Oxazolone-Induced Atopic Dermatitis through Regulation of Calcium Channels, Orai-1 and TRPV3, and Mast Cell Activation. Evidence-based Complement. Altern. Med. 2017, 2017, 1-12. [CrossRef] [PubMed]

44. Tosun, F.; Tanker, M.; Tosun, A. Alkaloids of Tribulus terrestris L. Growing in Turkey. Fabad J. Pharm. Sci. 1994, 19, 149-151.

45. Bourke, C.; Stevens, G.; Carrigan, M. Locomotor effects in sheep of alkaloids identified in Australian Tribulus terrestris. Aust. Vet. J. 1992, 69, 163-165. [CrossRef]

46. Ranjithkumar, R.; Alhadidi, Q.; Shah, Z.A.; Ramanathan, M. Tribulusterine Containing Tribulus terrestris Extract Exhibited Neuroprotection Through Attenuating Stress Kinases Mediated Inflammatory Mechanism: In Vitro and In Vivo Studies. Neurochem. Res. 2019, 44, 1228-1242. [CrossRef]

47. Ko, H.J.; Ahn, E.K.; Oh, J.S. N-trans-q-caffeoyl tyramine isolated from Tribulus terrestris exerts anti-inflammatory effects in lipopolysaccharide-stimulated RAW 264.7 cells. Int. J. Mol. Med. 2015, 36, 1042-1048. [CrossRef]

48. Lee, H.H.; Ahn, E.K.; Hong, S.S.; Oh, J.S. Anti-inflammatory effect of Tribulusamide D isolated from Tribulus terrestris in lipopolysaccharide-stimulated RAW264.7 macrophages. Mol. Med. Rep. 2017, 16, 4421-4428. [CrossRef]

49. Zhang, X.; Wei, N.; Huang, K.; Tan, Y.; Jin, D. A new feruloyl amide derivative from the fruits of Tribulus terrestris, Nat. Prod. Res. 2012, 26, 1922-1925. [CrossRef]

50. Javaid, A.; Anjum, F.; Akhtar, N. Molecular Characterization of Pyricularia oryzae and its Management by Stem Extract of Tribulus terrestris. Int. J. Agric. Biol. 2019, 1256-1262.

51. Vadakkan, K.; Vijayanand, S.; Hemapriya, J.; Gunasekaran, R. Quorum sensing inimical activity of Tribulus terrestris against gram negative bacterial pathogens by signalling interference. 3 Biotech 2019, 9, 1-6. [CrossRef] [PubMed]

52. Zhang, X.; Guo, Z.; Li, J.; Ito, Y.; Sun, W.; Heart, N. A new quantitation method of protodioscin by HPLC-ESI-MS/MS in rat plasma and its application to the pharmacokinetic study. Steroids 2016, 106, 62-69. [CrossRef] [PubMed]

53. Zhang, X.; Li, J.; Ito, Y.; Sun, W. Simultaneous quantification of five steroid saponins from Dioscorea zingiberensis C.H.Wright in rat plasma by HPLC-MS/MS and its application to the pharmacokinetic studies. Steroids 2015, 1, 16-24.

54. Tang, Y.N.; Pang, Y.X.; He, X.C.; Zhang, Y.Z.; Zhang, J.Y.; Zhao, Z.Z.; Yi, T.; Chen, H.B. UPLC-QTOF-MS identification of metabolites in rat biosamples after oral administration of Dioscorea saponins: A comparative study. J. Ethnopharmacol. 2015, 165, 127-140. [CrossRef] [PubMed]

55. Bors, W.; Heller, W.; Michel, C.; Saran, M. Flavonoids as antioxidants: Determination of radical-scavenging efficiencies. Methods Enzymol. 1990, 186, 343-355. [PubMed]

56. Aboul-Enein, H.; Kruk, I.; Kladna, A.; Lichszteld, K.; Michalska, T. Scavenging effects of phenolic sompounds on reactive oxygen species. Biopolymers 2007, 86, 222-230. [CrossRef]

57. Durgawale, P.P.; Datkhile, K.D. Study of Polyphenol Content and Anti- Oxidative Potential of Tribulus terrestris Dry Fruit Extract. Int. J. Pharmacogn. Phytochem. Res. 2017, 9, 716-721.

58. Zheleva-Dimitrova, D.; Obreshkova, D.; Nedialkov, P. Antioxidant activity of Tribulus terrestris - a natural product in infertility therapy. Int. J. Pharm. Pharm. Sci. 2012, 4, 508-511.

59. Dutt-Roy, R.; Kayalvizhi, E.; Chandrasekhar, M. Evaluation of the antidepressant activity of Tribulus terrestris in diabetic depression in rat model. Int. J. Pharm. Sci. Res. 2017, 8, 5392-5399.

60. Pamela C., C.; Harvey, R.A.; Ferrier, D.R. Lippincott Biochimie Ilustrată; Ediția a 4; București: Editura Medicală Callisto: București, Romania, 2010. 
61. Marnett, L.J. Lipid peroxidation - DNA damage by malondialdehyde. Mutat. Res. 1999, 424, 83-95. [CrossRef]

62. Amin, A.; Lotfy, M.; Shafiullah, M.; Adeghate, E. The protective effect of Tribulus terrestris in diabetes. Ann. N. Y. Acad. Sci. 2006, 1084, 391-401. [CrossRef] [PubMed]

63. Khaleghi, S.; Bakhtiari, M.; Asadmobini, A.; Esmaeili, F. Tribulus terrestris Extract Improves Human Sperm Parameters In Vitro. J. Evidence-Based Complement. Altern. Med. 2017, 22, 407-412. [CrossRef] [PubMed]

64. Kam, S.C.; Do, J.M.; Choi, J.H.; Jeon, B.T.; Roh, G.S.; Hyun, J.S. In Vivo and in Vitro Animal Investigation of the Effect of a Mixture of Herbal Extracts from Tribulus terrestris and Cornus officinalis on Penile Erection. J. Sex. Med. 2012, 9, 2544-2551. [CrossRef] [PubMed]

65. Pavin, N.F.; Izaguirry, A.P.; Soares, M.B.; Spiazzi, C.C.; Mendez, A.S.L.; Leivas, F.G.; dos Santos Brum, D.; Cibin, F.W.S. Tribulus terrestris Protects against Male Reproductive Damage Induced by Cyclophosphamide in Mice. Oxid. Med. Cell. Longev. 2018, 2018, 1-9. [CrossRef]

66. Yin, L.; Wang, Q.; Wang, X.; Song, L.-N. Effects of Tribulus terrestris saponins on exercise performance in overtraining rats and the underlying mechanisms. Can. J. Physiol. Pharmacol. 2016, 94, 1193-1201. [CrossRef]

67. Ghanbari, A.; Moradi, M.; Raoofi, A.; Falahi, M.; Seydi, S. Tribulus terrestris Hydroalcoholic Extract Administration Effects on Reproductive Parameters and Serum Level of Glucose in Diabetic Male Rats. Int. J. Mophol. 2016, 34, 796-803. [CrossRef]

68. Haghmorad, D.; Mahmoudi, M.B.; Haghighi, P.; Alidadiani, P.; Shahvazian, E.; Tavasolian, P.; Hosseini, M.; Mahmoudi, M. Improvement of fertility parameters with Tribulus Terrestris and Anacyclus Pyrethrum treatment in male rats. Int. Braz. J. Urol. 2019, 45, 1043-1054. [CrossRef]

69. Oliveira, N.N.P.M.; Félix, M.A.R.; Pereira, T.C.S.; Rocha, L.G.P.; Miranda, J.R.; Zangeronimo, M.G.; Pinto, J.E.B.P.; Bertolucci, S.K.V.; Sousa, R.V.D. Sperm quality and testicular histomorphometry of wistar rats supplemented with extract and fractions of fruit of Tribulus terrestris L. Brazilian Arch. Biol. Technol. 2015, 58, 891-897. [CrossRef]

70. Gauthaman, K.; Adaikan, P.G.; Prasad, R.N.V. Aphrodisiac properties of Tribulus Terrestris extract (Protodioscin) in normal and castrated rats. Life Sci. 2002, 71, 1385-1396. [CrossRef]

71. Kamenov, Z.; Fileva, S.; Kalinov, K.; Jannini, E.A. Evaluation of the efficacy and safety of Tribulus terrestris in male sexual dysfunction-A prospective, randomized, double-blind, placebo-controlled clinical trial. Maturitas 2017, 99, 20-26. [CrossRef]

72. Santos, C.A.; Reis, L.O.; Destro-saade, R.; Luiza-reis, A.; Fregonesi, A. Tribulus terrestris versus placebo in the treatment of erectile dysfunction: A prospective, randomized, double-blind study. Actas Urol. Esp. 2014, 38, 244-248. [CrossRef] [PubMed]

73. Milasius, K.; Dadeliene, R.; Skernevicius, J. The influence of the Tribulus terrestris extract on the parameters of the functional preparedness and athletes' organism homeostasis. Fiziol. Zh. 2009, 55, 89-96. [PubMed]

74. Iacono, F.; Prezioso, D.; Illiano, E.; Romeo, G.; Ruffo, A.; Amato, B. Sexual asthenia: Tradamixina versus Tadalafil $5 \mathrm{mg}$ daily. BMC Surg. 2012, 12, S23. [CrossRef] [PubMed]

75. Aguirre, G.A.; Ita, J.R.; Garza, R.G.; Castilla-Cortazar, I. Insulin-like growth factor-1 deficiency and metabolic syndrome. J. Transl. Med. 2016, 14, 1-23. [CrossRef] [PubMed]

76. Neychev, V.K.; Mitev, V.I. The aphrodisiac herb Tribulus terrestris does not influence the androgen production in young men. J. Ethnopharmacol. 2005, 101, 319-323. [CrossRef] [PubMed]

77. Rogerson, S.; Riches, C.J.; Jennings, C.; Weatherby, R.P.; Meir, R.A.; Marshall-Gradisnik, S.M. The effect of five weeks of Tribulus terrestris supplementation on muscle strength and body composition during preseason training in elite rugby league players. J. Strength Cond. Res. 2007, 21, 348-353.

78. Banihani, S.A. Testosterone in males as enhanced by onion (Allium cepa 1.). Biomolecules 2019, 9, 75. [CrossRef]

79. Phillips, O.A.; Mathew, K.T.; Oriowo, M.A. Antihypertensive and vasodilator effects of methanolic and aqueous extracts of Tribulus terrestris in rats. J. Ethnopharmacol. 2006, 104, 351-355. [CrossRef]

80. Malavige, L.; Levy, J. Erectile dysfunction and diabetes mellitus. J. Sex. Med. 2009, 6, 1232-1247. [CrossRef]

81. Vale, F.B.C.; Zanolla Dias de Souza, K.; Rezende, C.R.; Geber, S. Efficacy of Tribulus Terrestris for the treatment of premenopausal women with hypoactive sexual desire disorder: A randomized double-blinded, placebo-controlled trial. Gynecol. Endocrinol. 2018, 34, 442-445. [CrossRef]

82. Fatima, L.; Sultana, A. Efficacy of Tribulus terrestris L. (fruits) in menopausal transition symptoms: A randomized placebo controlled study. Adv. Integr. Med. 2017, 4, 56-65. [CrossRef] 
83. Akhtari, E.; Raisi, F.; Keshavarz, M.; Hosseini, H.; Sohrabvand, F.; Bioos, S.; Kamalinejad, M.; Ghobadi, A. Tribulus terrestris for treatment of sexual dysfunction in women: Randomized double-blind placebo-Controlled study. Daru 2014, 22, 40. [CrossRef] [PubMed]

84. World Anti-Doping Agency (WADA). Endogenous Anabolic Androgenic Steroids Measurement and Reporting. WADA Tech. Doc. - TD2016EAAS 2016, 1-16.

85. Tag, H.; Abdelazek, H.; Mahoud, Y.; El-Shenawy, N. Efficay of Tribulus terrestris extract and metformin on fertility indices and oxidative stress of testicular tissue in streptozotocin-induced diabetic male rats. African J. Pharm. Pharmacol. 2015, 9, 861-874.

86. Zhang, H.; Tong, W.T.; Zhang, C.R.; Li, J.L.; Meng, H.; Yang, H.G.; Chen, M. Gross saponin of Tribulus terrestris improves erectile dysfunction in type 2 diabetic rats by repairing the endothelial function of the penile corpus cavernosum. Diabetes, Metab. Syndr. Obes. Targets Ther. 2019, 12, 1705-1716. [CrossRef] [PubMed]

87. Mohammed, M.J. Biological Activity of Saponins Isolated from Tribulus terrestris ( Fruit) on Growth of Some Bacteria. Tikrit J. Pure Sci. 2008, 13, 3.

88. Jindal, A.; Kumar, P.; Gautam, K. Evaluation of antibiotic potential of alkaloids of Tribulus terrestris L. against some pathogenic microorganisms. Int. J. Green Pharm. 2013, 7, 102-105. [CrossRef]

89. Soleimanpour, S.; Sedighinia, F.S.; Safipour Afshar, A.; Zarif, R.; Ghazvini, K. Antibacterial activity of Tribulus terrestris and its synergistic effect with Capsella bursa-pastoris and Glycyrrhiza glabra against oral pathogens: An in-vitro study. Avicenna J. phytomedicine 2015, 5, 210-217.

90. Batoei, S.; Mahboubi, M.; Yari, R. Antibacterial activity of Tribulus terrestris methanol extract against clinical isolates of Escherichia coli. Herba Pol. 2016, 62, 57-66. [CrossRef]

91. Recio, M.C.; Rios, J.L.; Villar, A. Antimicrobial activity of selected plants employed in the Spanish Mediterranean area. Part II. Phyther. Res. 1989, 3, 77-80. [CrossRef]

92. Kianbakht, S.; Jahaniani, F. Evaluation of Antibacterial Activity of Tribulus terrestris L. Growing in Iran. Iran. J. Pharmacol. Ther. 2003, 2, 22-24.

93. Böttger, S.; Hofmann, K.; Melzig, M.F. Saponins can perturb biologic membranes and reduce the surface tension of aqueous solutions: A correlation? Bioorganic Med. Chem. 2012, 20, 2822-2828. [CrossRef] [PubMed]

94. Bangham, A.; Horne, R. Action of saponin on biological cell membranes. Nature 1962, 4858, 952-953. [CrossRef] [PubMed]

95. Ercan, P.; El, S.N. Inhibitory effects of chickpea and Tribulus terrestris on lipase, alpha-amylase and alpha-glucosidase. Food Chem. 2016, 205, 163-169. [CrossRef] [PubMed]

96. Ponnusamy, S.; Ravindran, R.; Zinjarde, S.; Bhargava, S.; Ravi Kumar, A. Evaluation of traditional Indian antidiabetic medicinal plants for human pancreatic amylase inhibitory effect in vitro. Evidence-based Complement. Altern. Med. 2011, 2011,1-10. [CrossRef] [PubMed]

97. Zhang, S.; Qu, W.; Zhong, S. Inhibitory effects of saponins from Tribulus terrestris on alpha-glucosidase in small intestines of rats. Zhongguo Zhong Yao Za Zhi 2006, 31, 910-913.

98. El-Tantawy, W.H.; Hassanin, L.A. Hypoglycemic and hypolipidemic effects of alcoholic extract of Tribulus alatus in streptozotocin-induced diabetic rats: A comparative study with T. terrestris (Caltrop). Indian J. Exp. Biol. 2007, 45, 785-790.

99. Lamba, H.S.; Bhargava, C.S.; Thakur, M.; Bhargava, S. $\alpha$-glucosidase and aldose reductase inhibitory activity in vitro and antidiabetic activity in vivo of Tribulus terrestris L. (dunal). Int. J. Pharm. Pharm. Sci. 2011, 3, 270-272.

100. El-Shaibany, A.; Al-Habori, M.; Al-Tahami, B.; Al-Massarani, S. Anti-hyperglycaemic activity of Tribulus terrestris L aerial part extract in glucose-loaded normal rabbits. Trop. J. Pharm. Res. 2015, 14, 2263-2268. [CrossRef]

101. Kalailingam, P.; Kannaian, B.; Tamilmani, E.; Kaliaperumal, R. Efficacy of natural diosgenin on cardiovascular risk, insulin secretion, and beta cells in streptozotocin (STZ)-induced diabetic rats. Phytomedicine 2014, 21, 1154-1161. [CrossRef]

102. Tharaheswari, M.; Jayachandra Reddy, N.; Kumar, R.; Varshney, K.C.; Kannan, M.; Sudha Rani, S. Trigonelline and diosgenin attenuate ER stress, oxidative stress-mediated damage in pancreas and enhance adipose tissue PPAR $\gamma$ activity in type 2 diabetic rats. Mol. Cell. Biochem. 2014, 396, 161-174. [CrossRef] [PubMed]

103. Soldatov, V.O.; Shmykova, E.A.; Pershina, M.A.; Ksenofontov, A.O.; Zamitsky, Y.M. Imidazoline receptors agonists: Possible mechanisms of endothelioprotection. Res. Results Pharmacol. 2018, 4, 11-19. [CrossRef] 
104. Samani, N.B.; Jokar, A.; Soveid, M.; Heydari, M.; Mosavat, S.H. Efficacy of the Hydroalcoholic Extract of Tribulus terrestris on the Serum Glucose and Lipid Profile of Women With Diabetes Mellitus: A Double-Blind Randomized Placebo-Controlled Clinical Trial. J. Evidence-Based Complement. Altern. Med. 2016, 21, NP91-NP97. [CrossRef] [PubMed]

105. Ramteke, R.; Thakar, A.; Trivedi, A.; Patil, P. Clinical efficacy of Gokshura-Punarnava Basti in the management of microalbuminuria in diabetes mellitus. AYU (An Int. Q. J. Res. Ayurveda) 2012, 33, 537-541. [CrossRef]

106. Karakas, M.; Schäfer, S.; Appelbaum, S.; Ojeda, F.; Kuulasmaa, K.; Brückmann, B.; Berisha, F.; Schulte-Steinberg, B.; Jousilahti, P.; Blankenberg, S.; et al. Testosterone levels and type 2 diabetes-No correlation with age, differential predictive value in men and women. Biomolecules 2018, 8, 76. [CrossRef]

107. Navarro, G.; Allard, C.; Xu, W.; Mauvais-Jarvis, F. The role of androgens in metabolism, obesity, and diabetes in males and females. Obesity 2015, 23, 713-719. [CrossRef]

108. Kim, H.J.; Kim, J.C.; Min, J.S.; Kim, M.J.; Kim, J.A.; Kor, M.H.; Yoo, H.S.; Ahn, J.K. Aqueous extract of Tribulus terrestris Linn induces cell growth arrest and apoptosis by down-regulating NF- $\mathrm{kB}$ signaling in liver cancer cells. J. Ethnopharmacol. 2011, 136, 197-203. [CrossRef]

109. Hong, C.H.; Hur, S.K.; Oh, O.J.; Kim, S.S.; Nam, K.A.; Lee, S.K. Evaluation of natural products on inhibition of inducible cyclooxygenase (COX-2) and nitric oxide synthase (iNOS) in cultured mouse macrophage cells. J. Ethnopharmacol. 2002, 83, 153-159. [CrossRef]

110. Ghareeb, D.A.; ElAhwany, A.M.D.; El-Mallawany, S.M.; Saif, A.A. In vitro screening for anti-acetylcholiesterase, Anti-oxidant, Anti-glucosidase, Anti-inflammatory and anti-bacterial effect of three traditional medicinal plants. Biotechnol. Biotechnol. Equip. 2014, 28, 1155-1164. [CrossRef]

111. Mohammed, M.S.; Alajmi, M.F.; Alam, P.; Khalid, H.S.; Mahmoud, A.M.; Ahmed, W.J. Chromatographic finger print analysis of anti-inflammatory active extract fractions of aerial parts of Tribulus terrestris by HPTLC technique. Asian Pac. J. Trop. Biomed. 2014, 4, 203-208. [CrossRef]

112. Qiu, M.; An, M.; Bian, M.; Yu, S.; Liu, C.; Liu, Q. Terrestrosin D from Tribulus terrestris attenuates bleomycin-induced inflammation and suppresses fibrotic changes in the lungs of mice. Pharm. Biol. 2019, 57, 694-700. [CrossRef] [PubMed]

113. Bourke, C.A. Staggers in sheep associated with the ingestion of Tribulus terrestris. Aust. Vet. J. 1984, 61, 360-363. [CrossRef] [PubMed]

114. Chauhdary, Z.; Saleem, U.; Ahmad, B.; Shah, S.; Shah, M.A. Neuroprotective evaluation of Tribulus terrestris L. In aluminum chloride induced Alzheimer's disease. Pak. J. Pharm. Sci. 2019, 32, 805-816. [PubMed]

115. Song, S.; Fajol, A.; Chen, Y.; Ren, B.; Shi, S. Anticonvulsive effects of protodioscin against pilocarpine-induced epilepsy. Eur. J. Pharmacol. 2018, 833, 237-246. [CrossRef]

116. Abudayyak, M.; Jannuzzi, A.T.; Özhan, G.; Alpertunga, B. Investigation on the toxic potential of Tribulus terrestris in vitro. Pharm. Biol. 2015, 53, 469-476. [CrossRef]

117. Aslani, M.; Movassaghi, A.; Mohri, M.; Pedram, M.; Abavisani, A. Experimental Tribulus terrestris poisoning in sheep: Clinical, laboratory and pathological findings. Vet. Res. Commun. 2003, 27, 53-62. [CrossRef]

118. Gandhi, S.; Srinivasan, B.P.; Akarte, A.S. Potential nephrotoxic effects produced by steroidal saponins from hydro alcoholic extract of Tribulus terrestris in STZ-induced diabetic rats. Toxicol. Mech. Methods 2013, 23, 548-557. [CrossRef]

119. Bourke, C.A. A novel nigrostriatal dopaminergic disorder in sheep affected by Tribulus terrestris staggers. Res. Vet. Sci. 1987, 43, 347-350. [CrossRef]

120. Hemalatha, S.; Hari, R. Acute and subacute toxicity studies of the saponin rich butanol extracts of Tribulus terrestris fruits in wistar rats. Int. J. Pharm. Sci. Rev. Res. 2014, 27, 307-313.

121. Talasaz, A.H.; Abbasi, M.R.; Abkhiz, S.; Dashti-Khavidaki, S. Tribulus terrestris-induced severe nephrotoxicity in a young healthy male. Nephrol. Dial. Transplant. 2010, 25, 3792-3793. [CrossRef]

122. Campanelli, M.; De Thomasis, R.; Tenaglia, R.L. Priapism caused by “Tribulus terrestris". Int. J. Impot. Res. 2015, 28, 39-40. [CrossRef] [PubMed]

123. Ryan, M.; Lazar, I.; Nadasdy, G.M.; Nadasdy, T.; Satoskar, A.A. Acute kidney injury and hyperbilirubinemia in a young male after ingestion of Tribulus terrestris. Clin. Nephrol. 2015, 83, 177-183. [CrossRef] [PubMed]

124. Selvaraju, R.; Thiruppathi, G.; Raman, R.G.; Dhakshanamoorthy, D. Estimation of Essential and Trace Elements in the Medicinal Plant Tribulus Terrestris By Icp-Oes and Flame Photometric Techniques. Rom. J. Biol. Plant Biol. 2015, 56, 65-75. 
125. Hassa, L.; Umar, K.; Umar, Z. Antinutritive factors in Tribulus terrestris (Linn.) leaves and predicted calcium and zinc bioavailability. J. Trop. Biosci. 2007, 7, 33-36.

126. U.S. National Library of Medicine. Available online: https://chem.nlm.nih.gov/chemidplus/ (accessed on 23 April 2020).

(C) 2020 by the authors. Licensee MDPI, Basel, Switzerland. This article is an open access article distributed under the terms and conditions of the Creative Commons Attribution (CC BY) license (http://creativecommons.org/licenses/by/4.0/). 